\title{
Dijital Emek ve Kullanıcı İçeriğinin Metalaşması: Katılımcı Sözlük Yazarları Üzerine İnceleme
}

\author{
Kenan Duman (Dr. Öğr. Üyesi) \\ İstanbul Arel Üniversitesi İletişim Fakültesi \\ kenanduman@arel.edu.tr \\ Güven Özdoyran (Dr. Öğr. Üyesi) \\ İstanbul Arel Üniversitesi İletişim Fakültesi \\ guvenozdoyran@arel.edu.tr
}

Başvuru Tarihi: 30.04.2018

Yayına Kabul Tarihi: 22.06.2018

Yayınlanma Tarihi: 30.07.2018

Öz

İnternet teknolojileri ve sosyal medya uzun bir süredir toplumsal hayatın önemli bir parçasıdır. Sosyal medya araçlarında kullanıcıların faaliyetleri ve bunun internet ekonomisinde yeri dijital emek kavramı ile iş olarak görülmeyen üretim biçimleri içinde bir dizi duygusal ve sosyal aktiviteyi kapsar. Dijital emek, çevrimiçi medya için bilgi ve içerik oluşturulurken ödenmemiş emeğin sömürülmesi olarak tanımlanır. Bu çalışma, emek-dijital emek, "somut-soyut (maddi olmayan) meta karşıtlıklarını incelemeyi, bu türden maddi olmayan emek ve metaların niteliğini araştırmayı, dijital emek ve içerik üretim süreci üzerindeki etkisini ve olumlu/olumsuz yönlerini tartışmayı amaçlamaktadır. Bu amaç doğrultusunda, Türkiye'de katılımcı sözlüklerde yazan kullanıcılar ile yapılan derinlemesine görüșmelerin analizi ile sosyal medya kullanıcılarının eğilimlerinin neler olduğu ortaya konulmuştur. Sosyal ağlarda ve katılımcı sözlüklerdeki deneyimleri tartışarak bunun emek ile ilişkisi ve farkını açıklayan araștırmada ayrıca katılımcı sözlük yazarlarının kişisel verilerinin ikincil kullanımı hakkındaki düşünceleri de tespit edilmeye çalışılmıştır. Çalışma da özellikle kullanıcıların katılımcı sözlüklerde yazma ve çalışma süresini bir "mesai" olarak tanımlamamakta, bunu daha çok "eğlence" olarak gördükleri ortaya çıkmıştır. Ayrıca kullanıcıların katılımcı sözlüklerde geliştirdikleri aidiyet duygusu ve kimliğin önemi tespit edilmiştir.

Anahtar Kelimeler: Dijital Emek, Katılımcı Sözlükler, Yeni Medya, Sosyal Medya, Katılımcı Kültür. 


\title{
Commodification of Digital Labor and User Content: A Review on Participant Dictionary Writers
}

\author{
Kenan Duman (Asst. Prof. Dr.) \\ Istanbul Arel University Faculty of Communication \\ kenanduman@arel.edu.tr \\ Güven Özdoyran (Asst. Prof. Dr.) \\ Istanbul Arel University Faculty of Communication \\ guvenozdoyran@arel.edu.tr
}

Date Received: 30.04.2018

Date Accepted: 22.06.2018

Date Published: 30.07 .2018

\begin{abstract}
Internet technologies and social media are a long-standing part of social life. The activities of users in social media tools and their place in the internet economy include a range of emotional and social activities in forms of production that are not seen as work with the concept of digital labor. Digital labor is defined as the exploitation of unpaid work while creating information and content for online media. This study aims to examine the contradictions and positive/negative aspects of the digital labor and content production process, examining the contradictions of concrete-abstract (non-material) commodities, investigating the nature of such intangible labor and commodities. For this purpose, with the analysis of in-depth interviews with the users of participant dictionaries in Turkey, the trends of social media users were revealed. By discussing experiences in social networks and participant dictionaries, we also tried to identify the thoughts of the secondary use of participant dictionary writers' personal data in research that explains the relationship and awareness of labor. The study also revealed that users do not define the duration of writing and working in participant dictionaries as "overtime" but rather see it as "fun". In addition, it was found out that the sense of belonging and identity that users developed in the participant dictionaries.
\end{abstract}

Keywords: Digital Labor, Participatory Dictionaries,New Media, Social Media, Participant Culture. 


\section{Giriş}

Hem klasik, hem eleștirel ekonomi politiğin odağı, tarihsel, toplumsal ve maddi koşullar, dijital olmaktan uzak üretim araçları, bu araçların mülkiyeti, araçlar ile üretilen metaların mübadele değeri ve üretilirken kullanılan kol emeğini merkeze alan, son derece tanımlı, sinırlılıkları "görsel" ve/veya dijital değil ama "maddi" ve "somut" olan araştırma nesneleri idi. Böylelikle, bu nesneye yönelik yapılan analiz veya tahliller belli bir çerçeveden veya paradigmadan yola çıkmayı mümkün kılıyordu. Öte yandan, yaşadığımız çağda, araștırma nesnemiz olan sosyal medya platformları bu türden bir kesinliği, hatlılığı ve sınırlılığı fersah fersah aşan, kendi içinde griftlikler taşıyan, tam da bu yüzden çetrefil ve kozasını açtıkça yeni kozalarla karşılaşılan, bir başka ifadeyle, kodlarını çözdükçe yeni kodlar üreten çok katmanlı bir fenomen olarak karşımıza çıkar. Tarihsel ölçekte söyleyecek olursak, meselenin bu türden güçlükler barındırmasının normal olduğunun altının çizilmesi gerekmektedir. Söz konusu fenomen, yani ekonomi politik bağlamında araştırma nesnemiz olan dijital medya, henüz yeni doğmuştur, ve ölü doğmak bir yana, kendi ethos'u tüm zenginliği ve heterojenliği ile bu toplumun ve toplumu oluşturan bireylerin ethos'u haline gelmiştir. Ve açıktır ki, bir nesnesinin en yalın haliyle "bilimsel araştırma nesnesi" haline gelmesi için belli bir zamansal sürenin geçmesi ve söz konusu fenomene "dışarıdan" bakılabilmesi için bir alan/mevzi sağlanması zorunluluğu açıktır. Fakat burada keskin bir paradoks ile karşı karşıya kalırız: Söz konusu mevziyi "zamanla" kazanamayacağımız aşikardır. Zamanla bu araştırma nesnesi müspet hale gelmez, bizi dışsallaştırıp karşısında mevzilenmemize izin vermez, tam tersine bütün muğlaklığı ile bizi daha da içine alır ve araştırma yapmak için konulması gereken belirli bir mesafeyi imkansız kılar. Bu anlamıyla güçlük, hem oyunun içinde kalıp, hem de oyunu dişarıdan izleyerek analiz edebilme güçlügüdür. Eğer meşru bir benzetme yapacak olursak, mevcut durumumuz psikanalizin ilk döneminde bilimsel bir araştırma nesnesi olarak ortaya çıkan "bilinçdışı"nın araştırılmasındaki güçlüğe benzer. Henüz söz konusu nesne için yeterli mesafeye ve "zaman"a sahip değilizdir. Diğer taraftan sosyal medyanın bir "apparatus" veya üretim/iletişim aracı olarak mülkiyeti, sermaye yapısı ve ürettiği metalar ile sıkı sıkıya bağlantılıdır. Buna göre, klasik üretim araçlarından tümüyle farklı olarak, burada üretici ve tüketici bir ve aynı ontolojik konuma sahiptir. Bir başka ifade ile söyleyecek olursak, dijital kültürde üreticiler aynı zamanda tüketicilerdir ve tam tersi. Bu ters düz ediş hali, klasik veya marksist ekonomi politik denklem açısından yeni paradigmaları, araştırmaları ve analizleri sadece mümkün değil ama aynı zamanda zorunlu hale getirmektedir. Önümüzde yepyeni bir fenomen tüm gizlilikleri ile durmaktadır. Web 2.0 teknolojisi ile gündemimize giren sosyal medya artık hem üreten-tüketen karşıtlığını hem pasif alıcı konumunu ortadan kaldırmıştır. Örneğin, Facebook, Twitter, Youtube, Ekşisözlük, İncisözlük veya Vikipedia gibi platformlar büyük sermaye yapılarına rağmen içerik üretmezler, bizatihi tüketici konumunda olan kullanıcılar aynı zamanda içerik üreticisi olarak karşımıza çıkarlar.

Bu durumda, bazı sorular kaçınılmaz olarak gündemimize gelecektir. Söz konusu sosyal medya platformlarının içerik üretimi aynı zamanda bir "meta" üretimi midir? Bir başka ifade ile Youtube'da paylaşılan bir video veya Ekşisözlük'te girilen bir "entry" klasik veya marksist iktisat açısından birer "meta" mıdır? Ekonomi politik "meta" kavramı" ile "dijital meta" kavramı bir ve aynı şeyi mi işaret etmektedir? Marx’ın artı-değer bağlamında ele aldığı "emek-emek gücü" ayrımı, söz konusu mecralarda işlerliğini devam ettirmekte midir? "Kullanım değeri-değişim değeri" 
ayrımı bir "üretim aracı" olarak "sosyal medya" platformlarında hala varlığını devam ettirmekte midir? Yoksa artık geçerliliğini yitirmiş midir? Baudrillard'a referansla söyleyecek olursak, artık söz konusu olan klasik "metaların mübadelesi" değil, ama "simgesel bir mübadele" midir? Bu sorulara en kestirmeden verilecek yanit, kaçınılmaz olarak sadece iktisadi değil ama ontolojik bir yanıttır: Artık "meta"nın ontolojik yapısı değişmiştir.

Son 30 yılın tarihsel dönüşümü üzerine bir tartışmanın içine girdiğimizde sözü edilen değişimin büyük çaplı etken paydasında ağın üzerine kurulmuş bir düzen karşımıza çıkar. Bu ağları Castells, birbirine değmeyen ağlar olarak niteler. Bu ağlarda bilgi işçileri emeklerini sergilerken tarihin hiçbir döneminde gülmeyen emeğin nerden çıkıp, nerede yönetildiği belirsiz bir hal oluşmuştur. Dijital çağdaki emek kavramından söz eden Fuchs, sosyal ağlarda oluşan ve kullanıcıya karşılığı verilmeyen bir emek sürecine vurgu yapar. Bu yeni düzende sosyal ağ içerisinde kullanıcıların oluşturduğu içeriğin internet ekonomisi için kâr mekanizması olurken kullanıcıya karşılığı verilmemektedir (Fuchs, 2010). Gönüllü olarak ağ içinde nasıl emek üretildiğini Fuchs ve Sevignani $(2013,237)$ oyun ve emek kavramlarını birleştirerek oluşturdukları playbour kavramı ile açıklarlar. Bu noktada dijital emek tartışması karşılığı ödenen emek ve karşılığı ödenmeyen emek olarak kategorize edilebilir. Fuchs ve Sevignani $(2013,255)$ dijital işi/emeği üç ayrı kategoride değerlendirmişlerdir: Bilişsel dijital iş, iletişimsel dijital iş, kooperatif dijital iş. Günümüzde özellikle "user generated content" kavramı kullanıldığında kooperatif dijital iş kavramı akla gelmektedir ve örneklemeler Vikipedia, Ekşisözlük ve benzeri platformlardan verilmektedir.

$\mathrm{Bu}$ çalışma kavramsal çerçeve oluşturmak amaçlı literatür taraması ve saha araştırmasından oluşmaktadır. Birinci bölümde dijital emek ve içerik üretim süreci ile katılımcı kültür kavramlarını literatür ve önceki araştırmalar üzerinden teorik arka plan incelenmiștir. İkinci bölümde de dijital alanda emek üretimini Türkiye'de web 2.0 teknolojisi gelmeden önce sosyal ağ yapısı oluşturma örneği olan katılımcı sözlüklerin yazarları ile yapılandırılmış derinlemesine görüşme tekniği ile araştırılmıştır. Çalışma, emek-dijital emek, "somut-soyut (maddi olmayan) meta karşıtlıklarını incelemeyi, bu türden maddi olmayan emek ve metaların niteliğini araştırmayı, dijital emek ve içerik üretim süreci üzerindeki etkisini ve olumlu/ olumsuz yönlerini tartışmayı amaçlamaktadır.

\section{Literatür Taraması}

\subsection{Dijital Emek ve İçeriğin Mülkleştirilmesi}

Marx'a göre, "meta" (commodity) en yalın haliyle pazarda alınıp satılmak için üretilen her şeydir. Toplumlar kendi varlıklarının maddi koşullarını üretmekle mükelleftirler. "Meta, bu türden bir üretimin değişim değeri aracılığı ile aldığı biçimdir." (Bottomore, 2005) Fakat yalnızca ilk bakışta meta bu kadar basittir. Burada kritik olan nokta meta'nın bir "biçim" /"form" olarak kodlanmasıdır. Marx'ın Hegel'den miras aldığı tarih merkezli teleolojisini dikkate alacak olursak, tarihin belli dönemlerinde toplumlar içinde bulundukları maddi koşulları hem üretirler hem de mevcut koşullara tabi olurlar, yani o koşullar tarafindan belirlenirler. 0 halde, meta, sabit bir maddi yapı arz etmekten ziyade, mevcut üretim araçları ve koşullarına göre farklı "biçimler" ve "formlar" olarak ortaya çıkar. Bu durumda, bizim de içinde var olduğumuz tarihsel ve maddi koşullar kendi üretim ilişkilerini ve metaları (biçim 
olarak) üretecek ve onları değiștirip dönüştürecektir. Unutmayalım ki Marx, içinde bulunduğu tarihsel/toplumsal koşullar açısından kapitalizmi ve kapitalist üretim ilişkilerini/yasalarını analiz eder. Onun açısından, mevcut araştırma nesnesini aşarak konuşmak lanetlediği "metafizik" bir tutum olacaktır. 0 halde, mevcut maddi koşulları, üretim araçlarını/ilişkilerini ve metaları yeni bir tarihsel paradigmadan analiz etmek marksist ekonomi politik açısından bir zaruret olarak karşımıza çıkar.

Bir başka önemli nokta, Marx'ın büyük önem atfettiği "kullanım değeri-değişim/ mübadele değeri" ayırımıdır. Marx açısından, kapitalist dönemi, insanlık tarihindeki diğer tüm dönemlerden ayıran en önemli nüans bu ayrım olacaktır. Buna göre, "kullanım değeri", kısaca, bir ürünün tüketim amacı, "faydasıdır." Örneğin, bir kalemin kullanım değeri, açıktır ki, onunla yazı yazılmasıdır. Burada, okuyucuyu asıl zorlayan fikir, fiyatlandırma, veya Marx'ın ifadesiyle "değerlendirme" aşamasında ortaya çıkar. Buna göre, kapitalist pazarda (piyasa) bir ürünün fiyatlandırılması onun kullanım değeri üzerinden gerçekleşmez, "değiş̧im/mübadele değeri" üzerinden gerçekleşir. Bir başka ifade ile, onun diğer metalar ile mübadele "gücü" üzerinden fiyatlandırılır. $\mathrm{Bu}$ anlamda, Marx piyasa/pazar darken "çok sayıda mübadele eyleminin aynı anda ve sürekli olarak gerçekleştirilmesine imkan veren toplumsal bir düzeneği" kasteder (Marx, 2008, 32). Bütün bu bilgiler ışığında, kapitalizmin kendisinden önceki tüm ekonomik rejimlerden ayıran temel unsurunun bu türden bir toplumsal düzenek olarak pazar/piyasa anlayışının olduğu görülür. Bu pazarda artık tüm metalar “homojen”leşir, çünkü ancak böyle bir türdeşleşme süreci sonucunda mübadele mümkün hale gelecektir. "Para" ise söz konusu mübadeleyi mümkün kllan temel parametre olacaktır. Para, "metaların metası olarak" mübadelenin yegane aracıdır. Peki tarihsel açıdan bu ne anlama gelmektedir? Örneğin, 13. Yüzyılda yaşayan bir serf, derebeyinin "şato"suna baktığında, orada uhreviyeti, ihtişamı, biat'ı, tanrının yeryüzündeki temsilcisinin ikametgâhını görür. Kapitalist özne için ise, feodalitedeki cemaat yapısının çözülmesi ile, "şato" artık sadece bir ve kendine denk şato değildir. 0 , mübadele piyasası içinde diğer metalar ile değiştirilebilen bir "meta"dır. Bir başka ifade ile şato dediğimiz yapı, aynı zamanda bir milyon ekmek, 20 tane apartman dairesi, iki fabrika vs.dir. Somut sınırlılığından kurtulmuştur. 0 artık "her şeydir". Marx "katı olan her şey buharlaşıyor" darken kastı kapitalist toplumlardaki bu türden bir kristalleşme halidir.

Bir başka önemli husus, Marx’a göre "sömürü" kapitalist sisteme dışarıdan eklemlenmiş, sonradan dahil olmuş bir kavram değildir. Kapitalist ekonomide "kâr" ancak "emek gücünün sömürülmesi" yolu ile ortaya çıkar. Dolayısıyla, kâr ile emek gücü sömürüsü neredeyse bir ve eş anlamlıdır. Sömürü, bu anlamıyla, kapitalizme içkin bir kavramdır.

Bütün bu anlatılanlar ışığında "dijital medya" veya "dijital emek" kavramlarına bakacak olursak, şunu söyleyerek başlamak isabetli olacaktır: Klasik anlamda belirli/ tanımlı bir "mekan" da ve belirli/tanımlı bir "zaman"da (somut) emeğin çalıştırıldığı "üretim aracı", merkezdeki konumuz bağlamında sosyal medya araçlarına evrilir. Bir başka ifade ile Facebook, Twitter vb. araçlar yalnızca iletişim araçları değil ama aynı zamanda "değer"-"Kâr" üreten "üretim araçları"dır. Denklemi bu şekilde kurduğumuzda, daha ilk bakışta klasik ekonomi-politik anlatının dijital medya bağlamında yetersizliği ortaya çıkar: Bir üretim aracı olarak, örneğin, Facebook artı değer veya meta üretirken ihtiyaç duyduğu emek gücü belirli/tanımlı bir "mekan"a veya belirli/tanımlı bir "zaman"a ihtiyaç duymaz. Tam da bu anlamıyla "emek" artık 
dijitalleşir, “dijital emek” dönüşür. Otonom Marksistlerin terminolojisini kullanacak olursak bu türden emeğe "maddi olmayan emek" diyebiliriz. Maddi olmayan emek, bizim örneğimizde "ücretsiz internet emek"ine dönüşür (Terranova 2000, 33).

Bir başka önemli nokta, üretilen meta'nın niteliğidir. Artık, maddi olmayan emek ile üretilen meta "somut" /"maddi" bir meta değildir, aksine o da soyutlaşır. Twitter ve Facebook örneğinde aynı türden (maddi olmayan) iki farklı meta söz konusudur:

1. İçerik

2. Kullanıcı Verisi/Kullanıcı verilerinin metalaşması

Hemen fark edebileceğimiz gibi, ontolojik olarak klasik meta kavramından ayrışan bu yeni tür metalar, tüketicileri tarafından üretilir. İlk olarak, "içerik üretimi" bizatihi Facebook ve Twitter kullanıcıları tarafından gerçekleştirilir. Üretilen bu içerikler vasıtasıyladır ki diğer kullanıcılar da söz konusu sosyal medyaya dahil olurlar veya dahil olmayı arzularlar. Nicel olarak artan kullanıcı sayıları ile içerik sayısı paralel olarak artar ve bu sayede elde edilen kullanıcı verilerinin sayısı da artacaktır. İçerik üretimi yoğun olan dijital araçlara reklam alımı yoğunlaşır, dahası burada içerik üreten kullanıcının verileri hedefli reklam odaklı olarak şirketlere satılarak metalaştırılır. "Verilerin metalaştırılması karşılığında Facebook ve Twitter, kullanıcılarına iletişim araçları sağlar. Bu araçlar, kullanıcıların kişisel verilerine erişim ve bu verileri metalaştırma imkanını şirketlere bağışlaması karşılığında sağlanan ayni yardımlar olarak değerlendirilebilir" (Fuchs, 2015, 136). Tam da bu paradoksal noktada Fuchs'un yadsınamaz ayrımı ortaya çıkmaktadır: Klasik (maddi) meta üretimi ve tüketimi sürecinde, kâr'ı ortaya çıkaran şey somut meta için tüketicinin belirli bir ücret öder. 0 ücreti ödedikten sonra tüketicinin para karşılığ elde ettiği metayı gerçekten tüketip tüketmemesi sermayedar için tümüyle ilgisizdir, çünkü kârı buradan elde etmez. Örneğin, Coca Cola şirketi için tüketicinin bir ücret ödeyerek Coca Cola alması kâr üretmek için yeterlidir. Burada kârın elde edilmesi için tüketicinin Coca Colayı tüketmesi zorunlu değildir. Bir başka ifade ile, "tüketim şirket için doğrudan değer yaratmaz" (Fuchs, 2015, 139). Öte yandan, yukarıda açıklamaya çalıştığımız dijital medyanın kendine özgü ekonomi-politiği içerisinde, Facebook ya da Twitter'da söz konusu "tüketimde tüm kullanıcıların bütün tüketim zamanı boyunca Facebook ve Twitter için" değer üretirler. Nihayetinde, meta üreten bir üretim aracı olarak Facebook ve Twitter'ın mülkiyetini elinde bulunduran sermaye, üretilen bu meta ile elde edilen kârı üreticisine, yani kullanıcıya bölüștürmez, yani bu meta veya artı değer üretimi için kullanıcıya herhangi bir ücret ödemez.

Bu noktayı daha iyi kavrayabilmek için, öncelikle, tüketici ile üretici nosyonları arasındaki farkın nasıl muğlaklaştığına dikkat çekmek istiyoruz. Tarihsel olarak bakıldığında üretici ile tüketici arasındaki çizginin bu derece muğlaklaşması, ya da daha doğru bir ifade ile iç içe geçmesi, "televizyon"un bir kâr amacı olarak ortaya çıkışı ile başlar. Smythe'ın çok isabetli vurgusunda olduğu gibi televizyon ile birlikte "izleyici metalaşır", bir başka ifade ile "izleyici metası" ortaya çıkar. Buna göre, bir meta olarak üretilen televizyon içerikleri izleyiciye belli bir ücret karşılığında sunulmaz. Burada tüketici, yani izleyici, izlediği içerik için belirli bir ücret ödemez. O halde burada kâr nasıl ortaya çıkar? Televizyon söz konusu olduğunda, kapitalist pazarda alınıp satılması için dolaşıma giren meta, televizyon içeriği değil, "izleyici sayısıdır". Bir başka ifade ile, pazarda alıcı, yani "reklam veren", televizyon içeriğine para ödemez, "izleyici sayısına" para öder. Alınıp satılan meta "izleyicidir". İzleyici, 
televizyon izlerken harcadığı zaman ile sermayedar için belirli türden bir meta da yaratmış olur. Buna benzer şekilde, dijital medyada da kullanıcı verileri pazarda reklam verenlere satılan metalara zorunlu olarak dönüșür. Böylelikle, üretici ile tüketici arasındaki mesafe tümüyle kapanmıștır. Alvin Toffler "üretketici kavramını 1980'lerin başında tanıtmıştır. Bunun anlamı "üreticiyi tüketiciden ayıran çizginin giderek bulanıklaşması"dır (Toffler, 1980, 267).

\begin{abstract}
"Metaları üreten üreticiler vardır, aksi halde var olamazlardı. Bu yüzden internet eğer internet platformlarında zikredilen meta, kullanıcı verisi ise, o zaman bu veriyi yaratma süreci de değer üreten emek olarak değerlendirilmelidir. Bunun anlamı şudur: Bu türden bir internet kullanımı, satılan bir meta ve değer yaratma bakımından bir üretken üretim veya üretüketim'dir." (Fuchs, 2015: 356)
\end{abstract}

Bütün bu tartışmalar, aslında, Adorno ve Horkheimer'ın “Kültür Endüstrisi” kavramı altında tartışmaya açtıkları "boş zamanın artık mesainin doğal bir uzantısı" olduğu tezine bizi geri götürür. Artık meta veya artı değer üretirken üre tüketicinin belirli bir zaman ve belirli bir mekâna ihtiyacı yoktur.

"Jhally (1987, 83) "seyretmek, fabrika emeğinin bir uzantısıdır" der ve oturma odamızın günümüzdeki fabrikalardan bir tanesi olduğunu savunur. Fabrika, ücretli emeğin alanıdır, ancak aynı zamanda oturma odalarımızda yer alır. Ücretli emek alanları dışında, fabrika sadece evimizde değil, her yerdedir. İnternet, aynı anda her yerde var olabilen bir fabrika ve izleyici metasının üretim alanıdır. Sosyal medya ve mobil internet, izleyici metasını her yerde bulunabilen bir hale getirir ve bu fabrika sadece oturma odanızla ve ücretli işyerinizle sınırlı değildir -fabrika arada yer alan bütün alanlardadır ve bütün gezegen, kapitalist bir fabrika haline gelmiștir."

O halde, Marx'ın ifadesini kasıtlı olarak deforme ederek söyleyecek olursak, artık katı olan emek, katı olan zaman, katı olan mekan, katı olan üretim aracı buharlaşıyor, çözülüyor ve soyutlaşıyor. Ancak Lazzarato'nun vurguladığı şu nokta unutulmamalıdır: Emeğin, metanın, üretim aracının ve bunlar yolu ile üretilen metanın maddi niteliğini kaybetmesine, soyutlaşmasına rağmen bunlardan elde edilen kâr hala somuttur (Peters ve Bulut, 2014, 257). Bu anlamılla da, Marx'ın "emek-sermaye çelişkisi" dediği kapitalizme içkin çelişki yerli yerinde durmaktadır. Fuchs'un $(2016,171)$ ifadesiyle, "izleyici emeği ve dijital emek, ticari sosyal medyada kesinlikle sömürülmektedir çünkü sömürünün üç şartı (Wright, 1997,10) verilidir.

- Biriken kâr, izleyiciyi ve kullanıcıları maddi kazanımlardan mahrum bırakmaktadır (ters karşılıklı- bağımlı refah).

- İzleyici ve kullanıcılar, medya organizasyonlarının mülkiyetinden ve birikmiş kârdan dışlanmaktadır (dışlanma).

- Sermaye, yaratılan kâra el koymaktadır (el koyma).

Böylelikle kapitalizmin yeni bir aşamasına geldiğimiz gerçeğinin altı çizilmelidir. "Facebook ve Google gibi ticari internet platformlarındaki kullanıcı emeğinin sömürülmesi, her zaman ve her yerde var olan bir fabrikanın emek sömürüsünün mekânı olduğu kapitalizmin yeni bir aşamasının göstergesidir. Sosyal medya ve mobil internet, izleyici emeğini her zaman her yerde var olan bir hale getirmekte ve fabrikayı sadece sizin oturma odanız ve ücretli işyerinizle sinırlamamaktadır. Fabrika ve işyeri gözetimi bütün ara yerlerde gerçekleşmektedir. Bugün, bütün bir gezegen fabrikadır" (Fuchs, 2015, 395). 


\subsection{Yeni Medya, Katılımcılık ve Kullanıcı Kaynaklı İçerik}

Mobil teknolojiler, dijital kameralar, internet uygulamaları, ses dosyaları, dijital televizyonlar gibi dijital iletişim araçlarına işaret eden bu yeniçağ yeni medya çağ olarak nitelenmektedir (Laughey, 2010, 158). Dijital sistemi üzerine kurulu iletişimin çift yönlü ve yoğun kapasiteli iletişim araçları ile gerçekleştirildiği yeni medya ortamı medya tüketicilerini pasif halden aktif hale geçirirken kendi istedikleri programları, kendi seçtikleri yayın araçlarından izledikleri yeni bir dönem başlatmıştır. Hedef kitle ile kaynak arasında sürekli bağlantı üzerine kurulu bu yeni dönemde dijital medya teknolojileri eski analog medyaların yerini almıștır. Kullanıcının dönüşüme uğradığı bu yeni mecranın ana dinamiklerinden birisi ise etkileşimdir. Web 2,0 dönemi olarak tanımlanan kullanıcı odaklı 2004 sonrası dönemde iletişim alanı için belirleyici gelişmeler meydana gelmiştir. Web 2.0 kullanıcı katılımına imkan veren, ortak alan oluşturan, dinamik veri kaynakları oluşturan ve zengin kullanıcı deneyimi yaratan özelliklere sahiptir. Web 2.0 teknolojisi kullanıcı katılımına imkân tanıyan yapısı ile sosyal medyaları oluştururken, kullanıcının yapısındaki dönüşüm sonucunda üre-tüketici olarak nitelendirilmeye başlar. Etkileşimin başka bir boyutunu oluşturan katılım, kullanıcı türevli içerik üretimine olanak sağlayan ortamlarda daha aktif bir şekilde yer alma biçimine atıf yapar. Bu yönüyle katılım ile etkileşim arasında görece bir fark oluşmaktadır. Katılımcılık etkileşime göre daha somut unsurlar barındırmaktadır. Örneğin sosyal medyada kullanıcıların oluşturdukları kimlik ile başlayarak ürettikleri ve dolaşıma soktukları yazılı, görselişitsel içerikler katılımcılığın somut göstergeleridir.

İnternet teknolojileri üretim ve iletişim aracı olarak, hem tüketici hem de üretici olan yenibir profil meydana getirmiştir. Internetkullanıcılarıkendi kullanıcı etkinliklerinin ve diğer kullanıcıların ürettiği içeriğin varlığını, kalıcı yaratıcı etkinlik, iletişim, topluluk inşası ve içerik üretiminde bulunduklarını fark etmektedirler (Fuchs, 2012, 43). Fuchs, $(2014,80)$ sosyal medya aracı olan Twitter ya da Facebook'un yalnızca iletişim aracı olarak değil aynı zamanda birer üretim aracı olarak değerlendirilmesi gerektiğini söyler. Fuchs'dan daha önce bu iki yönlü süreçten söz eden önemli bir isim 'Prosumer' terimini kullanarak Toffler olmuştur. Prosumer kavramı, producer (üretici) ve consumer (tüketici-müșteri) kavramlarının birleşmesinden oluşmuştur. Toffler, toplumun endüstri toplumundan post-endüstriyel çağa doğru yönlenişinde üretici ve tüketicinin prosumer haline geldiğini belirtir. üre-tüketici kavramı, üretici ve tüketici arasında var olan farkın, tüketicilerin üretim sürecine dahil olmaya başlaması ile belirsizleşmesi sonucunda ortaya çıkan yeni bir üretim-tüketim döngüsünü ifade etmektedir. (Toffler, 1996, 31) Axel Bruns bu terimi yeni medya alanında kullanarak kullanıcıların dijital bilgi ve teknolojisinin üreticisi haline geldiğini belirterek üreten tüketici kavramını kullanmıştır (Netchitaılova, 2012: 4).

Yeni medya; 20'inci yüzyılın 21'inci yüzyıla dönüştüğü zamanda ortaya çıkan hem bütünleşik hem de interaktif ve teknik araç olarak dijital kod ve hiper metni kullanan iletişim araçlarıdır. Yeni medyaya verilen en genel isimler multimedya, interaktif medya ve dijital medyadır. Bu tanımı kullanarak medyayı eski ve yeni olarak tanımlamak kolaydır. Örneğin klasik televizyonlar görüntü, ses ve metni içerdiği için bütünleşiktir ancak interaktiflik özelliğine sahip değillerdir ve dijital koda dayanmaktadırlar. Klasik telefonlar interaktiftir ancak sadece konuşma ve sesleri ilettikleri ve dijital kodla çalışmadıkları için bütünleşik sayılmazlar. Oysa yeni interaktif televizyon yeni bir iletişim aracı olarak hem interaktiflik özelliği hem 
de dijital kod kullanma özelliğine sahiptir. İlaveten, yeni mobil veya sabit telefon cihazları da metin, fotoğraf veya video ekleyebildikleri ve internete bağlandıkları için tamamen dijital ve bütünleşiktir (Dijk, 2016, 25)

1990’ların büyük bir kısmında internet web sayfalarını yapmak ve düzenlemek uzun süren, bütün değişikliklerin tek tek elle kodlandığı ve HTML dilinde yazıldı̆̆ı biçimde gerçekleşmiştir. 1990’ların sonlarına doğru programcılar web sayfalarını hızlı ve kolay şekilde düzenlemeyi sağlayan araçlar geliştirmişlerdir. Blog sayfalarının çoğalması ile birlikte, günümüzün internetinde bolca bulunan okunabilir/yazılabilir web sayfalarını yükselişi böyle başlamıștır. Web 2.0 terimi okunabilir/yazılabilir web anlamına gelmektedir. 2000'lerin başlarından beri insanlar internette ne yaptığını iyi şekilde tarif etmektedir. Bir web sayfasında bir şey okur, ardından ayını sayfaya okuduklarınız hakkında yazı yazarsınız. Sonrasından başka insanlar ne yazdığınızı okur ve cevap verir. İnternetin daha doğru bir tarifi "okunabilir/dinlenebilir/bakılabilir/izlenebilir- yazılabilir/ ses kaydedilebilir/fotoğraf ve video çekilebilir web" șeklinde olacaktır: internet çeşitli formatlarda mesajların hızlı yaratılmasını ve aktarılmasını sağlayıp, diyaloğu kolaylaştırır (Poe, 2015, 378). Yeni medya alanında web 2.0 sonrası gelişmeler kullanıcı kaynaklı içeriğe olanak verirken tam olarak 2004 sonrası dönemi işaret eden kavram web yayıncılığında içerik üretiminin yeni akımı olur. Bir sistem veya hizmet kullanıcıları tarafından oluşturulan ve bu sistemde herkese açık olarak sunulan içeriklere genel olarak verilen ad olan kullanıcı kaynaklı içerikleri sosyal medyalar, bloglar, wiki'ler, videolar, yorumlar veya sözlükler gibi alanlarda da yer alabilir. Kullanıcı kaynaklı içerikler hem medya kuruluşlarının sosyal ağların amatörlerin kendi içeriklerini yayınlayabilmelerini sağlamak kullandıkları bir alana dönüşürken ses, görünü ve video bu alanın temel yapıtaşları olur. İkinci iletişim devrimi ile kitle iletişiminin pasif tarafını oluşturan hedef kitle yeni medya ile bağımsız içerik oluşturabilen katılımcı kullanıcıya dönüştü. Aktif, katılımcı ve yaratıcı izleyici bugün nispeten erişilebilir medya, araçlar ve uygulamalar ile etkisini arttırmaktadır. Geleneksel araçlarla kıyaslandığında yeni medya araçları ile üretim içim uzmanlaşma ihtiyacı bulunmamaktadır. Daha az beceri gerektirir (Dijk, 2016, 296).

Castells, iletişim alanındaki yakınsamanın sadece teknolojik ve kurumsal olmadığını vurgulayarak çeşitli iletişim mod ve kanallarını birleştiren ve birbiriyle etkileșim kuran iletişimsel öznelerin akıllarında, düşünce şekillerinde ortaya çıktığını belirtir (Castells, 2016, 92). İletişim alanında yaşanan değişimleri göz önünde bulundurarak internetin yaygınlaşması ile "kitlesel öz iletişim" (mass self communication) olarak adlandırdığı yeni bir etkileşimli iletişim formunun ortaya çıktığını ileri sürer. Kitlesel öz iletişim, bireyin kendi oluşturduğu bir mesajı, yine kendi belirlediği alıcı/ alıcılara yönlendirmesi ya da kendi tercihleri doğrultusunda seçtiği içeriğe erişmesi açllarından da bir tür kendi kendine bir iletişimdir (Castells, 2016, 92). Castells'in yaratıcı süreci açıkladığı kitlesel öz iletişim dönemi Jenkins, katılımcı kültürel bir toplum kavramı ile açıklanır. Jenkins, (2016) katılımcı kültürü "hayranların ve diğer tüketicilerin yeni içeriğin yaratılmasına ve dolaşımına aktif olarak katılmaya davet edildiği'" kültür olarak tanımlamaktadır. Kullanıcı tarafından oluşturulan içeriğin yükselişe geçtiği bu yeni medya ortamı kullanıcıları giderek daha interaktif olanaklar kullanmakta ve diğerlerine sunulan medya içeriğine kendileri katkıda bulunmaktadır (Dijk, 2016, 319). 


\subsection{Katılımcı Sözlükler}

Web teknolojilerindeki gelişmelerle 1990 yılı sonrası dönemde katılıma olanak sağlayan sözlükler internet alanında yer almaya başlamıştır. Web 2.0 gibi etiket bazlı sistemlerin ürünleri olarak görülen sözlükler 2004 sonrası gelişmeler olarak bilinse de Türkiye'de Ekşisözlük gibi katılımcı sözlük platformlar 1999 yılında yayına bașlamıștır. Katılımcı sözlükler web üzerinde yer alan diğer statik sözlüklerden dinamik yapısı ile ayrılmaktadır. Uçkan, katılımcı sözlükleri "gerçek zamanlı akışa dayalı çevrim içi forumlar, topluluk yaratmaya odaklı sosyal ağlar, "urban dictionary" tarzı sözlük formatını kullanan kullanıcı içeriği siteleri ve ortaklaşa üretimin teknik altyapısını oluşturarak Vikipedia gibi örnekleri yaratan wiki'lerin bir karıșımı" $(2012,23)$ olarak tanımlamaktadır. Yakın ve Gürel ise sözlükleri "İnternet üzerinde faaliyet gösteren ve kelime ya da deyimleri alfabetik bir açılımla sunan platform" olarak $(2007,203)$ betimlerler.

Türkiye'de katılımcı sözlüklerin ilkleri arasında yer alan ve yaygınlaşan 1999 tarihinde oluşturulmuş olan Ekşi Sözlük, "her türlü kelime ve kavram hakkında kayıtlı yazarların yorumlarını içeren ve katılımcı sözlük özelliği gösteren bir web sitesidir ve sözcük, terim, kavram ve kişilere ilişkin bilgi, deneyim, gözlem, espri, yorum, anket, link ile kaynak içeren interaktif bir platform ve veri tabanı olarak tanımlanabilmektedir" (Gürel ve Yakın, 2007, 203-204). 2018 yılı nisan ayı rakamları ile Ekşi sözlük 10 milyona yakın gerçek tekil kişi tarafından takip edilmektedir. (İAB Türkiye, 2018) Türkiye'de internetin gelişimi ile paralel olarak yayınlanan Ekși Sözlük sosyal ağ bağlamında popüler bir mecra haline gelirken benzeri oluşumların da kurulmaya başlanmasına neden olur. 2004 yılında Web 2.0 kavramı daha yeni kullanılmaya başlanırken üniversite sözlükleri olan İtü Sözlük (2015 yılı itibariyle adı İnstela olmuștur) ve ardından Uludağ Sözlük yayına bașlamıștır. Güncel konulardan etkilenen katılımcı sözlüklere 2009'da İnci Sözlük katılmıștır. Diğer açılan sözlüklerin bazıları ise şöyledir: GS Sözlük, Kutup Sözlük, Süslü Sözlük, Dünya Sözlük, Nar Sözlük, Gezgin Sözlük, Blog Sözlük, Kirve Sözlük vb. İlk dönem katılımcı sözlükler, tematik sözlükler ve okul sözlükleri olarak kategorilendirilebilir.

Katılımcı sözlükler belirli bir konu ya da olay hakkında kolayca başlık açılarak yorum (entry) girebilmeyi sağlayan bir yapıdadır. Bu sözlüklerde Vikipedi benzeri yapılardan farklı olarak sadece ansiklopedik bilgi girilmemekte yazarlar aynı madde ile ilgili kendi görüşlerini açıklayarak tanımlara katkıda bulunabilmektedir. Bu yapısı nedeniyle katılımcı sözlükler farklı değişik görüşlerin ortaya konularak görüş çeşitliliğin sağlanmasına katkıda bulunur. Katılımcı sözlükler aynı dönemde popüler olan internet forumları ile elektronik sözlüklerin arasında bir yerdedir. Bu durum forumlardaki sübjektif ve kısıtlandırılmış yapı ile elektronik sözlüklerin tekil yapısı arasında etkileşimli bir yapı arası olarak betimlenebilir. Katılımcı sözlüklerin bu yapısı yeni medyanın tek bir medya değil çok sayıda ve belli bir heterojenlik içindeki medya ekolojisine işaret etmektedir. Günümüzde katılımcı sözlükler hem bilgi toplanılan hem üyelerin bir birlerini takip ederek güncel olaylarla ilgili bilgilere, değerlendirmelere yer veren ve özellikle gençlerin zaman geçirdiği sosyal ağlar hâline gelmiştir. Katılımcı sözlüklerin artan popülaritesi onu akademik araştırmaların önemli bir konusu haline getirmeye başlamıştır. Sözlükler son yirmi yıl içerisinde akademik çalışmalarında ilgi odağı konular arasında yer almaktadır. Katılımcı sözlük üzerine çalışmalar genel olarak söylem ve içerikler üzerine eğilimli olmuştur. 


\section{Yöntem}

Çalışmamız son 20 yıl içerisinde teknolojik alandaki gelişmelerle birlikte büyük bir dönüşüm gösteren internet alanında özel bir yeri olan sosyal ağları ve katılımcı sözlükleri kullanıcıların emek süreci ilişkisi bağlamında betimlemektir. Çalışma ile ilgili olarak katılımcı sözlükler ve kullanıcıları özeline indirgenmiştir.

\subsection{Araştırmanın Amacı}

Sosyal medya kullanıcısı tarafından oluşturulan içerik katılımcı sözlük iş modelleri tarafından da kullanılmaktadır. Bu çalışma, katılımcı sözlük yazarlarının ücretsiz içerik üretme ve emek konusunda eğilimlerini incelemeyi amaçlamaktadır.

Genel Soru: Sosyal ağlar ve katılımcı sözlüklerde kullanıcıların emek süreci ilişkisi nasıldır?

- Katılımcı sözlükler iletişim ve üretim aracı olarak nasıl konumlandırılır?

- Katılımcı sözlüklerde kullanıcı kaynaklı içeriğin motivasyon kaynakları nelerdir?

- Katılımcı sözlükte kullanıcıların emek süreci ve ücretsiz çalışma eğilimi nasıldır?

- Kullanıcılar sözlükte üretilen artı değer ve emeğin parçası mıdır?

- Katılımcı sözlükte kullanıcıların kişisel bilgilerinin ikincil kullanımı yazarlar için sorun oluşturmakta mıdır?

\subsection{Araştırmanın Metodolojisi}

Yeni medya teknolojilerindeki gelişmelerin sonucu olarak ortaya çıkan içerik aracı katılımcı sözlüklerdeki emek ve çalışma süreci eğilimlerini inceleyen bu çalışmada şu sorular yanıtlanmaya çalışılmıştır:

- Katılımcı sözlük yazarları için sözlüklerin gündelik yaşamlarındaki tanımı ve yeri nedir?

- Katılımcı sözlük yazarlarının sözlükte içerik üretirken motivasyonu nedir?

- Katılımcı sözlük yazarları sözlükte yazmayı emek ya da çalışma olarak görüyor mu?

- Katılımcı sözlük yazarları ürettiği içeriklerden kâr elde eden sözlük sahiplerini nasıl değerlendiriyor?

- Katılımcı sözlük yazarları kullanıcı bilgilerinin reklam verenlere ya da ikincil kurumlara verilmesi hakkında düşüncesi nedir?

Nitel çalışmada, metodolojik olarak Türkiye'de yer alan katılımcı yazarları ile gerçekleştirilen derinlemesine görüşmelerden elde edilen veriler yer almaktadır. Görüşmelerde daha iyi sonuç alınması için görüşme yapılanların kimlik bilgilerinin saklanacağı özellikle belirtilmiştir. Bu nedenle Tablo-1'de yalnızca yazdıkları sözlük, kodlama, eğitim ve yaş bilgilerine ilişkin 1'den 18'e kadar kodlar şeklinde verilmiştir. Ayrıca bulgularda kullanılacak doğrudan alıntılarda, görüşülen sözlük yazarlarının kimliklerini belirtmeyecek biçimde, sadece yazdığı sözlük, kod ve eğitimleri olarak yazılmıştır. Çalışmada örneklem olarak kartopu örnekleme tekniği kullanılmıştır. Araştırma evrenine konu olan büyüklügün sayısal olarak parametrik istatistik şartlarını sağlayamayacağı öngörülmektedir. Bu nedenle verinin sayısallaştırmaktan ziyade ifadenin vurgu ve sözsel anlamının nitelendirilebilmesi amacıyla olasılı̆̆a dayalı olmayan örneklem türlerinden kartopu örnekleme kullanılmıştır. Kartopu örnekleme yönteminde ilk olarak evrene ait birimlerin birisi ile irtibata geçilir. İrtibat kurulan birimin yardımıyla diğer birimlere gidilir. Bu biçimde, bir kartopunun büyümesi gibi örneklem büyüklüğü genişler (Yazıcıoğlu ve Erdoğan, 2004, 45). 
Buna uygun olarak Kartopu örnekleme tekniği ile belirlenen katılımcı sözlük yazarlarından 18 görüşme talebi kabul olmuştur. Çalışma katılımcı sözlük yazarları ile sınırlanmıştır. Çalışmada sosyal ağları ve katılımcı sözlükleri kullanıcıların emek süreci ilişkisi bağlamında betimlenmektedir. Çalışmanın veri toplama yöntemi literatür taraması ve katılımcı sözlük yazarları ile yapılan derinlemesine görüşme olarak belirlenmiş ve uygulanmıştır.

Araştırmanın Varsayımları:

1. Katılımcı sözlükler kullanıcılar tarafından hem iletişim, hem de üretim aracı olarak görülmektedir.

2. Katılımcı sözlük yazarlarının içerik üretirken temel motivasyonları "ücret" değil kimlik ve aidiyettir.

3. Katılımcı sözlük yazarları içerik üretirken bunu bir iş olarak görmemektedir.

4. Katılımcı sözlük kullanıcıları meta üretiminin bir parçasıdır.

5. Katılımcı sözlük yazarlarının ürettikleri içerikler ve kullanıcı verileri metaya dönüşmektedir.

Tablo 1: Örneklem Olarak Belirlenen Yazarlara Ait Bilgiler

\begin{tabular}{|c|c|c|c|}
\hline & YAZDIĞI SÖZLÜK & KODLAMA & Eğitimi \\
\hline 1 & Ekşi Sözlük & (K1 ekşi) & Lisans \\
\hline 2 & Ekşi Sözlük & (K2, ekşi) & Lisans \\
\hline 3 & Ekşi Sözlük & (K3, ekşi) & Lisansüstü \\
\hline 4 & Ekşi Sözlük & (K4, ekşi) & Lisans \\
\hline 5 & Ekşi Sözlük & (K5, ekşi) & Lisansüstü \\
\hline 6 & Ekşi Sözlük & (K6 ekşi) & Lisans \\
\hline 7 & Ekşi Sözlük & (K7, ekşi) & Lisans Öğrencisi \\
\hline 8 & Ekşi Sözlük & (K8, ekşi) & Lisans Öğrencisi \\
\hline 9 & Ekşi Sözlük & (K9, ekşi) & Lisans \\
\hline 10 & Ekşi Sözlük & (K10, ekşi) & Lisans \\
\hline 11 & Ekşi Sözlük & (K11 ekşi) & Lisans \\
\hline 12 & Ekşi Sözlük & (K12, ekşi) & Lisans \\
\hline 13 & Uludağ Sözlük & (K 13, Uludağ) & Lisans \\
\hline 14 & İnci Sözlük & (K 14, inci) & Lisans Öğrencisi \\
\hline 15 & Ekşi Sözlük & (K 15, ekşi) & Lisans \\
\hline 16 & İnstela & (K 16, instela) & Lisans \\
\hline 17 & Ekşi Sözlük & (K 17 ekşi) & Lisans Öğrencisi \\
\hline 18 & Dünya Sözlük & (K 18 Dünya) & Lisans \\
\hline
\end{tabular}

\subsection{Katılımcı Sözlüklerin İletişim ve Üretim Aracı Olarak Gücü}

Poe, $(2015,335)$ katılımcı sözlük benzeri alanlara neden katkı yaptığımızı sorar ve 'kendinden büyük bir şeyin parçası olmak', 'yardımlaşmacı bir topluluğun üyesi olmak' ya da 'basit bir şekilde can sıkıntısından kurtulmak' cevabını verir. Bu yanıtların yanında asıl olarak bu durumun gerçekleşmesinde evrimsel nedenlerin yer aldığını söyler. Çünkü internetin dev bir sunum oyununa benzediğini ve bu oyuna insanlığın bayıldığını vurgular. Tim O'Reilly Web 2.0'ın aktüel değişimleri ifade ettiğini şüphesiz düşünse de, kullanıcıların bir kollektif zeka olarak, bağlantılı kullanıcılar topluluğu olan Google, Amazon, Wiki, Craiglist gibi platformların değerini birlikte yaratma konusunda çok önemli olduklarını söyler. (O’Reilly ve Battele, 2009, 1) Bu çalışmada katılımcı sözlüklerin bu kadar revaçta olmasının, kullanıcıların bu sosyal alanlara 
rağbet göstermesinin sebebi araştırılırken iletişim ve üretim aracı olarak da sözlükler değerlendirilmiştir. Görüşmelerin sonucu olarak burada ortak olarak anonim kimlik, eşitlik hissi ve iletişim alanı olarak kullanımı genel olarak vurgulanabilir.

Genellikle kullanıcıların içerik ve kültür yaratmaya dâhil olması için kullanılan katılımcı kültür teriminin (Jenkins, 2008, 331) ilk dönem araçları arasında yer alan katılımcı sözlükler yeni dönem bireyin iletişim ve üretim biçiminin göstergesidir. $\mathrm{Bu}$ bölümde katılımcı sözlük yazarlarının gündelik yaşamınız içinde ne olarak tanımladıkları görüşülen katılımcılara sorulmuștur. Genel olarak 18 katılımcının cevaplarına göre sözlüklerde yer alma nedenleri 5 madde ile özetlenebilir.

- Gündemi takip etmek

- Fikirlerini özgürce paylaşmak ve sosyalleşmek

- Başvuru Kaynağ

- Zaman geçirme aracı

- Yazar olma hissi

Gürel ve Yakın (2007), ekşi sözlük özelinde katılımcı sözlükleri değerlendirirken doğrunun ve bilginin yanı sıra toplumsal bazda etkili olan pek çok tabu ve değerin sorgulanmasına aracılık ederek kendine özgü bir kültür oluşturduğunu ifade etmişlerdir. İnternetin gelişimi ile birlikte kullanıcılara aynı anda üretme olanağı sunan sözlükler etkileşim alanı haline gelmiştir. Özellikle öncü olması bağlamında Ekşi Sözlük yarattığı jargonla, interaktif ve özgün içeriğe imkân veren yapısıyla ve gündelik yaşama dair her şeyin tartışılabildiği ve eleştirilebildiği bir ortam olmasının da etkileriyle diğer ağlardan ayrılarak dikkat çekmiştir (Taşdemir ve Çevik, 2013, 30).

Başvuru Kaynağı: Katılımcı sözlükler biçim ve tür bakımından genel sözlüklerden farklı olarak içeriklerinin sübjektif olma potansiyeli mevcuttur. Dijital sözlükler ve Vikipedi gibi yapılar üyelerin ya da yöneticilerin ortak olarak hazırladıkları oluşumlardır. Katılımcı sözlükler ise sadece ansiklopedik madde madde bilgilerden oluşmayan kullanıcıların kendi düşünce ve görüşlerini tanımsal olarak girdikleri verilerden oluşur. Farklı düşünce ve görüşlerin yaklaşık 20 yıldır oluşturduğu bilgi birikim nedeniyle çoğu internet kullanıcısı katılımcı sözlükleri referans kaynağı olarak kullanmaktadır. Görüşemeye katılan katılımcılardan iki tanesi bilgi kaynağı olarak katılımcı sözlükleri kullandığını belirtmiştir.

"Müthiş bir veri birikimi her zaman ulaşllabilecek bir şekilde orada duruyor. Entelektüel veya gündelik konularda ilk başvuru kaynaklarımdan biridir." (K1, ekşi)

"Her ne için google'da aramaya yapıyorsam, öncelikli olarak işe sözlükten başlarım. Eğer söz konusu şeyle ilgili bir entry yoksa kendim yazarım." (K10, ekşi)

Gündemi takip etmek: Dijital kültür içerisinde kullanıcılar özellikle iletişim araçların mobilize olma özelliği ile sürekli içeriğe erişmektedir. Katılımcı sözlük içerisinde kullanıcıların genellikle madde başlıkları kamuoyunu ilgilendiren gündeme ilişkin konulardır. Böylece yazarlar ve okurlar sözlüklerde genişleyen ve güncellenen içeriğe her an ulaşma ve takip etme olanağı bulurlar. Görüșemeye katılan katılımcılardan altı tanesi gündemi katılımcı sözlüklerden takip ettiğini belirtmiştir.

\footnotetext{
"Sözlük bilgi ve haber kaynağım, stres topum, keşif alanım. Yani ekrandan takip edilen sanal bir alana göre günümün dikkate değer bir kısmını kaplıyor." (K2, ekşi)

“Sözlüğü gündelik yaşamımda, bir haber alma aracı ve gündemi(popüler olanı) takip etme aracı olarak kullanıyorum." (K5, ekși)
} 
“Sözlük günlük haberleri öğrendiğim yer" (K7, ekşi)

"Haber alma, bilgi alma, varolan güncel ülke durumu ile ilgili başlıkları kontrol etme, takip ettiğim başllklara girilen içerikleri okuma amaçlı." (K8, ekşi)

"Sözlük benim için gündelik yaşamda daima güncel bir haber kanalı." (K9, ekși)

"Günün gündemini, sosyal olayları ve sosyalleşmemi çoğunlukla sözlük ile sağllyorum." (K 13, uludağ)

Fikirlerini özgürce paylaşmak ve sosyalleşmek: Sözlükler, yazarların belirli konulara ilişkin görüşlerini, özgür ve yaratıcı ifadelerle belirtme imkânına sahip olması bakımından internet forumlarından farklılık göstermektedir.

"Derin tartışmaların döndüğü başlıklarda yazmayı, okumayı özel bir çeșit sosyalleșme türü olarak kabul ediyorum.” (K2, ekşi)

“Gündeme ilişkin veya gündemden bağımsız olarak bilgi ve yorumlarımı paylaşabildiğim bir ortam sağlıyor." (K3, ekşi)

"Entelektüel bir havuz gibi. Ama son zamanlarda kalitesiz yazarların artması ya da her çaylağın koşulsuz yazar olması sözlüğün genelini biraz bozdu gibi." (K6 ekşi)

"Sözlük insanlarla iletişime geçtiğim yer olarak görüyorum. Özellikle her kesimden insanın olması fikir ve düşüncelerini duymak ve ekşi sözlüğün mottosu olan "kutsal bilgi kaynağı" olması her bilgiye rahatça ulaşmak ve spesifik entelektüel bildikleri büyük bir havuzun içinden süzmek olduğunu söylemek mümkün zira aynı şekilde insanlarla bilgi vermek görmediklerini göstermek bir konuda uyarmak hareket geçirmekte olduğunu söyleyebiliriz" (K7, ekşi)

“Günün gündemini, sosyal olayları ve sosyalleșmemi çoğunlukla sözlük ile sağllyorum. Yazdığımdan çok okuyorum. Farklı görüşleri görmek için de iyi oluyor. Çok sayıda insanla tanıştım sözlükler sayesinde." (K 13, Uludağ)

“Eskiden benim mekanım derdim. Sosyal medyanın bence ilk örneğidir çünkü.” (K 15, ekşi)

“Güzel arkadaşlıklar kazandırdı bana, en mühimi bu kendi açımdan.” (K 17 ekşi)

Zaman Geçirme Aracı: Shirky, (2011, 27) sosyal medyayı boş zamanlarımızı paylaşılmış küresel kaynak olarak işletmemize ve bu kaynağın avantajlarından faydalandığımız, paylaşımın ve katılımın yeni türlerini tasarlamamıza yarayan alan olarak tanımlar. Görüşmeye katılan katılımcılar ortalama olarak her gün 1 -2 saat arası değişik zamanlarda sözlüklerde zaman harcamaktadırlar. 2 katılımcı ise haftanın bazı günleri sözlükte zaman harcadığını belirtmiştir.

"Benim kafamı dağıttı̆̆ım bir yer. Çok yoğun çalıştığım için nefes aldığım bir yer olarak tanımlıyorum.” (K12, ekși)

“Benim yazı yazdığım sözlük diğer sözlüklerden farklı. Eğlenceli ve özgür bir bilgi paylaşımı var. Zaman geçirmek için sözlükteyim.” (K 14, inci)

Yazar olma hissi: Katılımcı sözlükler kullanıcıların hiyerarşik yapılanması (nesil), yazarların birbirleri ile etkileşim içinde olabilmesi ve entelektüel yapısı ile kısa süre içerisinde kullanıcıların içinde bulunmak için motive oldukları sosyal ağlar içerisinde yer almışlardır. Özellikle ekşi sözlükte yazar olma süresi ve şartlarının zorluğu nedeniyle katılım için olumlu yönde etki yapmıştır. Ekşisözlük'ün yazar alımlarında titizliği sözlükte yazmanın herkesin ulaşamayacağı önemli bir yapıya dönüștürmüștür. Bu durum, sonrasında sözlük yazarı olanların daha popüler hale gelmesini sağlamıştır. 


\begin{abstract}
“Sözlüğ̈̈ gündelik yaşamım içerisinde içerik üretebildiğim katılıma olanak tanıyan bir medya gibi görüyorum." (K3, ekși)

"Bundan 10 yıl önce gün içinde çok düşünürdüm sözlüğe birşeyler yazmalıyım falan diye. $O$ zaman çok havalı birşeydi. Ama son zamanlarda aklıma bile gelmediği oluyor." (K4, ekşi)

"Samimi olmak gerekirse, sözlük yazarlyım dediğimde bir ortamda insanların "hadi yaa nick'in ne"diye sorularına karșın esrarengiz davranmanın bende yarattığı o havalı duygu... Hep hoşuma gitmiştir." (K11, ekşi)
\end{abstract}

\title{
2.4. Katılımcı Sözlüklerde Kullanıcı Kaynaklı İçeriğin Motivasyon Kaynakları
}

Tamamen kullanıcı tarafından oluşturulan içeriğe dayanan katılımcı sözlükler için kullanıcı etkileşiminin sürekliliği önemli bir sorunsaldır. Yaklaşık 20 yıllık katılımcı sözlük ve sosyal medya örnekleri gösterdiği gibi kullanıcılar üretmek istiyor ve kendi oluşturdukları bilgileritüketmeye devam ediyorlar. Kullanıcıların içerikoluşturdukları ve karşılığında maddi bir ücret almadıkları bu yapı içerisinde kullanıcıları sürekli olarak içeriküretmeye motive eden nedir? Bu sorunun yanıtını Ritzer ve Jurgenson'dan ödünç alarak cevaplarsak bireylerin kazanımlarının görmezden gelinemeyeceği bu ortamda çoğu kullanıcı içerik oluşturma ve ortamı kullanmaktan zevk almaktadır. Elbette Marksist literatürde bunların hepsinin "sahte bilinç" in modern bir versiyonu olduğunu iddia edebilir. Bununla birlikte, muhtemelen kullanıcıların bu şeyleri yapmaktan gerçekten çok hoşlandıkları ve basitçe manipüle edilmeleri daha muhtemeldir. (Ritzer ve Jurgenson, 2010, 25) Çalışma için gerçekleştirdiğimiz görüşmelerde katılımcı sözlük yazarları sözlükte yazmalarının motivasyon kaynağı ortak olarak üç kavramı ön plana çıkarmışlardır. Bunlar;

- Otomatik dinleyiciye sahip olmak

- Anonimlik

- Ortak Entellektüel Çalışma Mekânı (İçeriğe katkıda bulunmak)

Otomatik dinleyiciye sahip olmak: Turkle; (2015) kimsenin bizi dinlemediği hissinin teknolojiyle aramızdaki ilişkide çok önemli bir rolü olduğunu altını çizer. Bu nedenler kullanıcıların sosyal ağa sahip olma konusunda daha istekli hale geldiğini söyler. Turkle'a göre kimsenin bizi dinlemediği hissi bizi umursuyormuş gibi görünen makinelerle daha çok zaman geçirmemize sebep olmaktadır. Görüşemeye katılan katılımcılardan dört tanesi okuduğunu bilmek ve dinlenilmenin sözlükte yazmak için motivasyon kaynağı olduğunu belirtmiştir.

"Sözlükte yazdığım zamanlar akademik not defteri gibi kullanmayı tercih ediyorum.
Başkalarının okuduğu düşüncesi notları daha akılda kalıcı yapıyor." (K1 ekşi)
"Kendi deneyimlerimi paylaşıyor olmam ve buna benzer deneyimler yaşayan kişilerle
etkileşim sağlamak." (K8, ekşi)
"Okunmak yorum almak çok bilinir olmak en büyük motivasyon kaynağıdır" (K 13,
Uludağ)

“Bir entry'de bana gönderme gördüğümde bayağı bir mutlu olurdum." (K 15, Uludağ)

$\mathrm{Bu}$ türden bir söylemin bir paradoksu içerdiğini söyleyebiliriz. Buna göre, "okunduğunu bilme" ve "dinlendiğini bilme" meselesi cemaat kodları içerisinde "öteki"nin, yani cemaatin diğer üyelerinin "onayını talep etme" biçiminde tezahürünün mümkün olduğunu düşünüyoruz. Cemaatin diğer üyeleri tarafından "onaylanma" ihtiyacı, "simgesel ağ"da var olmanın, yani, belirli türden bir kimliğe sahip "özne" olarak "yer kaplamanın" zorunlu bir gereğidir. Öte yandan, söz 
konusu dijital platformlarda üretilen "provokatif" içerikleri dikkate alacak olursak, meselenin yalnızca "onaylanma" değil, ama aynı zamanda "provoke etme" yolu ile "görünür" olma meselesi olduğu da söylenebilir. Birbiri ile çelişir gözüken her iki durumda da kullanıcı "görünür" olma vasıtasıyla "var olur". Berkeley'in ifadesi ile "Esse est percipi" ("varolmak algılanmaktır") Özetle, kullanıcıların içerik üretirken motivasyonlarından bir tanesi "görünür" olma/algılanır olma vasıtası ile "var olma" ihtiyacıdır, denilebilir.

Anonimlik: Sosyal ağlarda ve özellikle çalışma alanımız olan katılımcı sözlüklerde kullanıcılar, gerçek yaşamlarından farklı bir biçimde kendilerini özgür ifade edebilmelerine olanak tanıyan anonim bir yapı ile karşı karşıyadırlar. Günümüzde yaşanan kültürel dönüşümün sonucu olarak yalnızlık ve yabancılaşma olgularına karşı, bireylere sistem karşıtı, sınırların olmadığı imkanlar sunmaktadır. Bu açıdan yazarlar için sözlükler, "egemen kültür ve söylemlerini -tüketim, mülkiyet, para, bilgi, güzellik, başarı vb.- reddederek gerçek anlamda özgürleşme ve yeniden doğmaya çalıştıkları" mekân olarak tanımlanmaktadır (Gürel ve Yakın, 2007, 210). Görüşemeye katılan katılımcılardan üç tanesi anonim yapının sözlükte yazmak için motivasyon kaynağı olduğunu belirtmiştir.

\begin{abstract}
"Yazarken cinsiyetim, adım, mesleğim, vücut ölçülerim anonim fakat hakim olduğum konular konusunda bir şeyler birakırken kim olduğum bilinmeksizin binlerce hatta milyonlarca kişiye ulaşabileceğim fikri beni heyecanlandırıyor. Insanlar çoğu zaman istemsiz olarak diğer insanlara karşı pek çok kodlama taşırlar, onları etiketler ve gardlarını alırlar. Anonim bir kaynaktan akan fikirler çoğunlukla ön yargılar ya da sahte beğenilerden arındırılmış oluyor." (K2, ekși)
\end{abstract}

"Görüşlerimi paylaşırken kimliğimi gizli tutması özgürce düşüncemi ifade etmem konusunda daha motive edici oluyor" (K3, ekși)

"Anonim olduğum için biraz daha özgür hissettiğimi söyleyebilirim. Bu da beni motive ediyor. Neticede her yaptığımızın, söylediğimizin gözetlendiği bir zamanda yaşıyoruz. Kendim olarak yorum yapmaktansa, takma bir isimle yorum yapmak, görüş belirtmek daha güvenli geliyor." (K6 ekşi)

Ortak Entellektüel Çalışma Mekânı (İçeriğe katkıda bulunmak): Katılımcı sözlüklerde kullanıcılar konuları ve gündem maddelerini yaratıcı biçimde ele alırlar. Kullanıcı tarafından oluşturulan içeriğin ortaya çıkması çevrimiçi içerik oluştururken amatörlerin kendi içeriklerini yayınlamalarına olanak sağlayarak önemli bir değişime neden oldu. Dijital kültürün insanı reel hayatta daha da yalnızlaștıran tarafına zıt biçimde, kullanıcı isimlerle dijital nesil katılımcı sözlüklerde sosyalleşerek, paylaşarak, eklenerek, genişleyerek var olmaktadırlar. Buradaki "yalnızlaşmasosyalleşme" paradoksunu çözmek için Renata Salecl'in "hiperkapitalizm” kavramına başvurmak gerektiğini düşünüyoruz. (Salecl, 2008, 63) Buna göre, kapitalist çağın alametifarikası olan "birey-bireysellik" (ki böyle olması Marx'ın "tarihin diyalektik ilerlemesi" kavramına denk düşer): Feodal üretim tarzında "cemaat" ve "cemaat ilişkileri" söz konusu iken, kapitalizm ile beraber, yani, kapital (sermaye) fikri ile beraber, cemaat ilişkileri çözülmeye başlar ve "birey” fikri gündeme gelir. Bu anlamıyla "birey" son derece "modern" bir kavramdır. Cemaat'ten Birey'e doğru bu türden bir evrilme anlamlıdır, zira sermaye birikimi için "özel mülkiyet”, özel mülkiyet” için "birey"e ihtiyaç vardır. Hiperkapitalist çağda tersine-evrim ile yerini tekrar cemaat'lere, bizim örneğimizde ise "dijital cemaat"lere bırakmaktadır. Böylelikle, belirli türden kimlik inşası, cemaat ve dolayısıyla bu cemaate aidiyet dolayımı ile mümkün hale gelir. Bir başka ifade ile, katılımcı sözlüklerdeki "maddi olmayan 
emek"in motivasyonu, kullanıcının "maddi olmayan kazancı", yani "kimlik" edinme, ile tanımlanır. Kullanıcı, ürettiği içerik yolu ile, dijital bir cemaatin üyesi haline gelir ve bu tanımlı sosyalizasyon dolayımı ile kendisine yeni bir tür "kimlik" edinir. Mevcut durumu şematize edecek olursak: Feodalite $\rightarrow$ Kapitalizm $\rightarrow$ Hiperkapitalizm'e denk düşen: Cemaat $\rightarrow$ Birey $\rightarrow$ Cemaat, denilebilir. Özetleyecek olursak, katılımcı sözlükte kullanıcı maddi olmayan emeği karşılığında, maddi olmayan bir kazanç elde eder: Kimlik. Dijital sözlüklerde kullanıcılar hem içeriğin üretimi gerçekleștirmekte hem de içeriğin tüketicisi olmaktadır.

\begin{abstract}
"Yazı yazmayı seviyorum ve sözlük fikirlerimi kim olduğumun/kimliğimin bir önemi olmadan yapmamı sağlıyor, buna benzer bir motivasyonla blog da yazıyorum. Aynı zamanda benzer konuları dert etmiş insanlarla fikir teatisinde bulunmak da önemli benim için" (K5, ekşi)

"İçerik üretirken çoğu zaman bir motivasyona ihtiyacım olmuyor. Daha çok "Bu konu hakkında benimde söyleyeceklerim, anlatacaklarım var" dediğim anlarda yazlyorum." (K9, ekşi)

"Kendi yaptığım gibi insanların Google'dan bir şey search ederken sözlükle mutlaka karşılaşıyor olmaları ve benim de orada yer alıyor olmam, birilerinin benim yazdılarımı okuyor ya da onlara gülüyor olması bana hala çok ilginç gelir mesela." (K10, ekşi)
\end{abstract}

\title{
2.5. Katııımcı Sözlükte Emek Süreci ve Ücretsiz Çalışma
}

Dijital medya söz konusu olduğunda Fuchs ideolojiyi iki biçim olarak tanımlar: "Sosyal medyayı bir katılımcı kültür ve yeni demokrasi biçimi olarak sunma" ve "oyun olarak sömürünün gizli görünümü". Fuchs'un buradaki hali ile "ideoloji”yi iki biçim olarak sunması örtük olarak Marx’ın "ideoloji” tarifine denk düşer. Marx’a göre "ideoloji” somut değil, soyuttur. Bir başka ifade ile ideoloji "içi boş bir kavramdır". İdeoloji, Marx açısından, yalnızca bir "biçim", "form”, bir "işlev" olarak vardır. Bu anlamıyla ideoloji, "sınıf savaşının” üzerini örten her şeydir. İdeoloji, sınıf savaşını ya görünmez kılar, ya da sınıflar arası çelişkiyi, sömürüyü, doğal veya "normal” gösterir. Fuchs'un ideolojiyi sınıflamasına bu perspektiften bakacak olursak şu hakikat bütün gerçekliği ile kendisini okuyucuya faş edecektir: Dijital medya ideolojiktir, çünkü: 1) Bir katılımcı kültür ve yeni demokrasi biçimi olarak sınıf savaşının üzerine örter 2) Oyun olarak sınıf savaşının, yani sömürünün, üzerine örter. Tam da bu noktada, aşağıda kullanıcıların bazılarının belirtmiş olduğu gibi, söz konusu sömürü, yani kullanıcıların hiçbir ücret almaksızın içerik üretmesi, yani emeğin sömürülmesi, kullanıcı açısından bir sorun teşkil etmiyorsa, burada Gramsci'nin "İdeolojik Hegemonya”-"Hegemonik İdeoloji” kavramına işaret etmek gerekmektedir. Denilebilir ki, kullanıcının burada içerik üretmesine, yani "meta" üretmesine rağmen ücret almamasını sorun etmiyor oluşu mevcut paradigmayı "burjuva değerleri" üzerinden okuyor oluşundan kaynaklanmaktadır; dünyaya "burjuva değerleri" ile bakmaktadır. Tam da bu yüzden, emeğinin karşılığının almaması onun açısından "doğal” ve "normal"dir. Bu biçimi ile kapitalizm, egemen bir ideolojinin dayatılmasıyla sürdürülmektedir. Kullanıcı tarafından oluşturulan içeriğin önemli bir sorunsalı katılımcıların bedava çalışma ( ‘bedava emek’) konusu yer almaktadır. Dijital medya içerisinde Vikipedi, Ekşisözlük ve açık kaynak yazılımı gibi fenomenler işbirliğini zevk ve ödüle dayandırmaya çalışan kültürel etkinliklerin örnekleri arasındadır. Dijital alanda çok daha fazla firma daha çok kullanıcılarının ve tüketicilerinin katılımı üzerine yapı kurmaya çalışmaktadır. Ücretsiz içerik veya ücretsiz bilgi, ücretsiz bir kültürel çalışmanın tanımını karşılayan her türlü işlevsel çalışma, sanat eseri veya diğer yaratıcı içeriklerdir. 
Sosyal medya bazlı ağ ilişkileri insanların internet üzerinden bilgi ve fikir üretmeleri ve paylaşmaları için bir araç olarak gelişmiştir. Bu yeni sosyal ağ ilişki biçimleri genellikle eğlence için dijital emeğin para kazanması işi eğlenceden ayıran çizgiyi bulanıklaştırmıştır. Sosyal ağlarda içerik şirketi ve kullanıcılar tipik sosyal medya kullanıcılarının dijital içeriği için herhangi bir parasal gelir almazken, şirketlerin gelirleri oluşturmak için bu serbestçe erişilebilen bilgilerden faydalanmaktadırlar. Sözlükte yazmayı emek ya da çalışma olarak görüyor musunuz? Şeklindeki sorumuza görüşemeye katılan katılımcılardan on tanesi emek olarak görmediklerini belirtmiştir. Bu durumu yine Castells'den ödünç alarak belirtirsek $(2016,104)$ "İnsanların girişimleri, çıkarları ve arzuları etrafında kurulan yatay bir iletişim"dir.

“Parasal karşılığı olması gereken bir emek olarak görmüyorum.” (K1 ekşi)

"Sözlük yazarlığı açısından bakıldığında bu bir "emek" veya "üretim"den ziyade "bilgi paylaşımı" veya "katkısı" veya "yorumu” şeklinde ifade edilebilir." (K3, ekşi)

“Hayır. Eğlence için bence.” (K4, ekşi)

"Sözlükte yazmak bir emek işi ama çalışma olarak nitelendirmiyorum. Mesainiz yok, bir zorunluluk yok. Tamamen keyfi." (K9, ekşi)

“Çalışma olarak görmüyorum. Ama ortada bir emek olduğu aşikar.” (K6 ekşi)

"Daha çok terapi ve bilgimi paylaşmak olarak görüyorum. Yazdığım yazı özel bir emek gerektiriyorsa da nadir olarak emek ya da çalışma olarak gördügüm zamanlar oldu." (K3, ekşi)

\footnotetext{
"Hayır görmüyorum, çalıșma kısıtlayıcı bir şey, sözlükse tam tersine özgürce yazabildiğim bir alan olarak görüyorum." (K5, ekşi)

“Ben bu platformu eğlence ve bilgi alanı olarak görüyorum.” (K 14, inci)

"Sözlükte yazmak ya da sözlüğü okumak benim için boş zamanım için bir aktivite emek olarak görmüyorum." (K 13, Uludağ)
}

Marx'ın "emek-değer kuramı" bir metanın fiyatlandırılmasında belirleyici olan parametreleri açılar. Buna göre, metaların kapitalist pazarda değişimini/ mübadelesini mümkün kılan parametre, bir başka ifade ile o metanın "değerini" belirleyen temel parametre "emek-zaman"dır. Yani, o metanın üretimi için harcanan zamandır. Aslında tam da bu yüzden, örneğin, fordist üretim tarzı veya "iş bölümü" kapitalizm için kritik kavramlardır. Bunlar sayesinde işçinin bir meta üretimi için harcadığı birim zaman kısalmış, böylece metanın fiyatı rekabet edilebilir seviyeye gelmiştir. Marx'ın bu “değer kuramı"nı, yeni medya'ya uyarlayacak olursak, öncelikle şunu söylemek gerekiyor: Kullanıcıların içerik üretmek, ki bu içerikler meta'ya dönüşmüştür, üzere harcadıkları süre, bu anlamıyla, belli türden bir emeği içeren "zaman”dır. Marx’a göre, üretim aracının sahibinin kâr etmesi için değerinin altında ücretlendirdiği işçinin emeği, yeni medya söz konusu olduğunda ücretlendirilmemiştir bile.

Yukarı da söz ettiğimiz soru ile ilgili altı görüşmeci sözlükte yazmayı ve emek ya da çalışma olarak gördüğünü belirtiyor.

\footnotetext{
“Makaleye dönüşmüş girdiler, kimi yazarların meslekleri, deneyimleri yoluyla elde edilmiş özel bilgiler sunulduğunu göz önünde bulundurarak kuşkusuz büyük bir emek varlığından söz etmek mümkün.” (K 2)

“Her yazdığımı emek olarak görmüyorum eğer bilgi veriyorsam tamam fakat bir bakınız
} 
veya kara mizah unsuru ise emek değil ama genel olarak bakarsam evet çünkü zamanımı orada harclyor ve yazıyorum. "(K7, ekşi)

"Burada içerik üretirken bunun emek olduğunun elbette farkındayım ama kendi içerisinde devinim halinde olan bir süreç desek daha faydalı olacaktır." (K8, ekşi)

“Tabi görüyorum. Mesela aklıma bir şey geliyor sözlükte var mı diye bakıyorum. Yoksa üstüne düşünüyorum nasıl yazabilirim diye. Mesai harclyorum yani. Bu ortada bir emek olduğu anlamina geliyor." (K10, ekși)

"Açık olmak gerekirse görüyorum ama bilinen bir yazar olmak için o emeği harcıyorum. Sözlükle aramdaki iliş̧kiyi bu şekilde niteleyemem." (K11, ekși)

"Görüyorum ve birilerinin benim ve benim gibi onlarca yazar üzerinden muhteşem sayılabilecek paralar kazanıyor olması canımı sıkıyor." (K15, ekşi)

Yukarıda belirtildiği gibi katılımcı sözlük yazarlarının üçte ikisi sözlükte gerçekleştirdikleri eylemleri çalışma olarak görmediklerini üçte biri ise çalışma olarak değil emek olarak değerlendirileceğini vurgulamışlardır.

\subsection{Sözlükte Üretilen Artı Değer ve Emeğin Parçası Olarak Yazarlar}

Fuchs, kullanıcılara ödeme yapılmamasına, boş zamanlarımda kullanma ve gündelik yaşama yardımcı olan eğlenceli bir faaliyet olarak görmeme rağmen sosyal medya kullanımı nasıl emek olabilir? sorusunu sorar. Emek nosyonu üzerine çalışan birçok akademisyen sömürünün gerçekleştiğini iddia etmektedir. Bu genellikle ödenmeyen bir şeydir, ancak içerik üzerinde hedeflenen reklamlarla ve kullanıcı bilgilerinin dağıtımı ile gerçekleşebilir. Görüşme yapılan katılımcılara sözlük bir üretim aracı olarak sizin ürettiğiniz içeriklerden kâr elde ederken yazarların hiçbir ücret almamasını nasıl değerlendiriyorsunuz? Sorusu yöneltilmiștir. Genel olarak katılımcılar bu soruda gönüllü bir üretim sürecinden söz etmişlerdir.

"Bilgi paylaşımının gönüllü olduğu mecraların olması gerektiğini düşünüyorum. Ayrıca, sözlük yarı ansiklopedik, seçkinci bir yapıdan daha demokratik, diğer sosyal medya sitelerine benzer bir hale dönüștü. Bu anlamda yazarlara para vermekten söz etmek daha da anlamsız olur." (K1 ekşi)

"Kâr elde etme amaçlı üretim yapmadiğımdan yani gönüllü bir üretici olduğumdan umursamiyorum. Ayrıca bunu bir proje olarak üreten, yazılımın yapan ekibin bunun üzerinden kâr etmesini oldukça normal buluyorum sonuçta know-how günümüzün en önemli değerlerinden birisi benim için." (K5, ekşi)

“Eğer karşıllğında para veriliyor olsaydı o kadar zekice ve harika enrty'ler yer almazdı sözlükte. Çünkü her rutin kaliteyi bozar. Sözlük kazaniyor evet kazansın da. Neticede sözlükte yazmayı bir iş olarak görmüyorum." (K6 ekşi)

"Pek fazla ilgilenmiyorum zira her sosyal medya platformu için geçerli bir durum. Yazma motivasyonu farklı olduktan sonra ücret konusu pek cezbetmiyor. Bu spesifik olarak bir teori olarak başkaları alsa bile şahsen beni pek ilgilendirmiyor. Sanıyorum ki internet sitelerinin bu tarz șekilde yürüyor olmasından dolayı itiraz edilebilecek bir husus olduğunu düşünmüyorum." (K7, ekşi)

"Sözlükte bizlere fikir beyan etme imkânı sunuyor. Her şeyin bir karşılığı var" (K9, ekși)

"Bu durum göreceli, sonuçta bize özgür bir konuşma alanı oluşturmaya çalışan platform var. Bu oluşum ticari bir oluşum. Yaşaması için maddi ihtiyaçları olabilir. Benim için bir sorun değil." (K 13, Uludağ)

Bütün bu tartışmalar ışığında, "gönüllü üretim" başlığı ile ilintili olarak, yukarıda Renata Salecl'e referansla tartıştığımız "cemaat" meselesini Negri'nin "Biyopolitika" 
nosyonu ile beraber okumanın üretken bir tavır olacağını düşünüyoruz. Buna göre, her ne kadar "Biyopolitika" kavramı Foucault açısından sadece ve yalnızca belirli bir tür "iktidar" tarzı iken, yani tümüyle "negatif" bir nitelik taşımasına rağmen, Negri için "biyopolitik üretim biçimleri" yeni bir toplumsal örgütlenme biçimi olanağını içinde barındırır. "Maddi olmayan emek" kategorisini Negri, "duygulanımsal emek" olarak tanımlar ve duygulanımsal emeğin ürettiği șeyin "toplumsal ağlar, "cemaat biçimleri" ve "biyoiktidar" olduğunu belirtir. Böylelikle, "dijital cemaat biçimleri" nin sağladığ imkan ile iletişimsel ve insani etkileşim yeni bir boyut ve "çoğulluk" kazanır. Burada bir kere daha görülebilir ki, ekonomik üretimin araçsal edinimi insani ilişkilerin iletişimsel edinimiyle birleşmiştir; bu durumda iletişim zayıflamamış ama üretim insani etkileşiminin karmaşıklığı düzeyine kadar erişecek kadar zenginleşmiştir. (Hardt ve Negri, 2005, 298)

Görüşme yapılan katılımcılardan iki tanesi sözlüklerin (özellikle Ekşisözlük) sosyal sorumluluk kampanyalarının öneminden söz etmiştir. Emeklerinin sosyal sorumluluklarda kullanılmasının önemli olduğunu belirtmiştir.

"Ben emek sarfederek ve severek/isteyerek birilerine fayda sağlarken, bu faydayı aynı zamanda reklam ve para olarak geri dönüş sağlayan Eksisözlük yönetimi tarafından değerlendirildiğinin farkındayım. Onlar da bazı durumlarda eksiseyler.com üzerinde paylaşım yaparlarsa her paylaşım icin bir fidan diktiklerini belirttiler, tabi ne kadar doğru, ne kadar yanlış bilemiyoruz." (K8, ekși)

"Sözlük bu konuya ilişkin olarak ssg yurtdışına gitmeden önce ekşi sözlük ormanı veya yardım faaliyetlerine katkıda bulunuyordu. Günümüzde sadece "ekși șeyler" sitesi üzerinde yazılarınız paylaşıldığında adınıza bir ağaç dikildiğini biliyorum. Sözlüğün genel olarak bir Hyde park gibi özgürce düşüncelerin paylaşılabildiği bir ortam yaratması bile benim için önemli." (K3, ekşi)

Jenkins, $(2001,93)$ medyada gerçekleşen yakınsama ile yeni bir katılımcı halk kültürünün doğduğuna dikkat çeker. Bu yeni kültür içerisinde sıradan insanların da medya içeriği üretebileceği araçların ortaya çıktığını söyler. Jenkins'e göre katılımcı kültür içerisinde insanlar medya içeriğine katkıda bulunurlarken, medya şirketlerinin düşük maliyetler ile içeriğe sahip olma gibi amatör içeriklerden yararlanmasına olanak sağladığını ve bu durumun kullanıcıyı sömürmesine olanak sağladığının altını çizer. Böyle bir durum karşısında tamamen kâr aramayan bir içerik sağlayıcı bulunabilir m sorusu akla gelir. Bu gün için önemli bir sorun alternatif bir sosyal mecranın mümkün olup olmadığıdır. Görüşme yapılan katılımcılardan bir tanesi bu durumun altını çizmektedir. "Teknik olarak çok adaletsiz ve can sıkıcı. Fakat yaşamın kuralları aşağı yukarı böyle işliyor. Sözlük kurulurken işsize iş, aça aş vaadinde de bulunmuyordu. Yaratıcı biri çıktı, kodunu yazdı biz de kendi motivasyon biçimlerimizi yaratarak dahil oluyoruz. Fakat elbette sözlük devasa sayılarla büyümeyi özenli yazarlar ve girdiler sağlama amacına tercih etmiş ve bu yönde düzenlemeler yapıyor gibi görünüyor. Yani daha dar ve seçkin bir yazar grubu olsaydı sözlük kazançlarına ortak olmaları daha gerçekçi ve adil olurdu. ...Benim için en ideali " kimsenin kazanç elde etmediği bir sözlük “fikri galiba.” (K2, ekşi)

Daha önce de belirtildiği gibi, kullanıcılar üretmeyi ve tüketmeyi, paylaşılacak içeriklerinizi oluşturmanın fayda sağladığını, özellikle de bunun benzer fikirlere sahip bireylerden oluşan bir toplulukla paylaşılabileceğini düşünmektedir. Bununla birlikte, bu, kişisel verilerin, pazarlama için kullanılan içeriğin imzalanması ve teslim edilmesi yoluyla bir sömürü yönünün üstlenilmediği anlamına gelmez. 


\subsection{Kişisel Bilgilerin İkincil Kullanımı ve Katılımcı Sözlük Yazarlarının Tutumları}

Sosyal medyanın kapitalist karakterinin yani kar mantığı, meta mantığı, hedefli reklamcılık ve sömürülen emeğin bir zorunluluk değil, internetin ticari ve kapitalist örgütlenmesinin tarihsel bir sonucu olarak karşımıza çıkmıştır. (Fuchs, 2016: 41) Sosyal medya ağlarında kullanıcılar tarafından oluşturulan içerik yer alır. Sosyal medya ağındaki içeriğin mülkiyeti konusu her zaman büyük bir tartışma olmuștur. Çünkü kullanıcılar tarafindan oluşturulan içerikler küresel ya da yerel şirketler tarafından barındırılmaktadır. Katılımcı sözlüklerde de kullanıcılar kedilerinin ürettiği içeriğe ticari olarak sahip olma hakkına sahip değildir. Katılımcı sözlükler ücretsiz bir uygulama olarak içerik paylaşmanızı sağlarken diğer sosyal medya ağları gibi içerikleri promosyon ve pazarlama amaçlı kullanma" hakkına sahip olmaktadır. Ancak Son Kullanıcı Lisans Sözleşmesinde 'İçerik' hakkında telifin kullanıcıya ait olduğunu belirtir. Örneğin ekși sözlükte "Ekși sözlük'te oluşturduğunuz/yayınladığınız içeriklerin telif hakları size aittir. bu nedenle ekşi sözlük'te yayınlandığınız içeriğinizi (entrylerinizi) ticari maksatla dahi dilediğiniz şekilde derleyip, kullanabilirsiniz. ancak ekşi sözlük'te yayında olan içeriklerinizi internet üzerinde başka bir sitede daha yayınlamanız halinde ekşi sözlük'e aktif link vermeniz gerekmektedir. ekşi, sourtimes, ekşi şeyler ve ekşi sözlük markalarının kullanımı ise ekşi teknoloji'nin yazılı iznine tabidir." şeklinde durum belirtilir.

Genel olarak sosyal medyada kişisel bilgilerin ikincil kişilere satılması, paylaşılması ya da başka bir şekilde kullanabileceğine dair endişeler vardır. İnternet alanında kullanıcılar için gizlilik büyük bir endişe nedenidir. Katılımcı sözlük gibi yaygın, popüler ve sosyal açıdan önemli bir şey için, bu sorular bizi birçok ilginç yere yönlendirebilmektedir. Katılımcı sözlük yazarlarına kullanıcı bilgilerinin reklam verenlere ya da ikincil kurumlara verilmesi hakkında düşünceleri sorulmuştur.

"Kullanıcı bilgilerimin paylaşılmasını gelecekte daha tehlikeli olacağını ön gördüğüm için çok zararlı ve rahatsız edici buluyorum." (K2, ekși)

\footnotetext{
"Önceden böyle bir durum yoktu ancak son yllarda içerik ile ilgili şikâyet veya dava edilme durumunda doğrudan ip ve tüm bilgilerimizin paylaşıldığı resmi olarak açıklandı. $\mathrm{Bu}$ süreçten sonra da zaten sözlüklerin içerik kalitesi ve konular/kişiler hakkında girilen entry'lerin de azaldığı bariz bir şekilde görülüyor. Bu kısaca kendi otosansürünü yarattı diyebiliriz." (K8, ekşi)
}

"Bu durum herkes için hassas bir durum. 6698 nolu Kișisel Verilerin Korunması Kanunu kapsamında bunu yakın zamanda önlenebileceğini düşünüyorum. Sözlüğün en güzel yanı anonim olabilmek iken verilerin ikincil kurumlara verilmesinin yazarlar için tedirgin oluşturabileceğini düşünüyorum." (K9, ekşi)

“Önemli bir sorun. Ama hergün kimler bilgilerimizi almiyor ki." (K 14, inci)

Katılımcı sözlükleri Web 2.0 sonrası sosyal ağlardan ayıran en önemli özelliği yukarıda tartıştığımız anonim yapısıdır. Kullanıcıların takma isim ve mail adresi ile bulundukları platform kullanıcılara daha serbest bir alan imkânı sunmaktadır. Görüşme yaptığımız katılımcılardan altı tanesi bu durumun altını çizmiştir.

"Kullanıcı sayfası içerisinde bu konuda yanılmiyorsam bir bilgi metni paylaşıllyordu. Sosyal medyada her türlü bilgimizin paylaşıldığı hakkında Günümüzde çok önemli bir sorun olarak görmüyorum. Bilgilerinizi ne kadar sözlükte paylaşıp paylaşmadığınız önemli. Tamamen kurgu bir kimlik yaratıp o kimlikle sözlükte yazarlık yapabilirsiniz." (K3, ekşi) 
“Bu durum tüm sosyal ağlar için bir sorun. Ben burada nick ile varlığım var. Mail adresi haricinde fazla bir bilgim de mevcut değil." (K 13, Uludă̆)

"Olmasa daha iyi olur ama bu nasıl değișebilir diye defalarca kez düşündüm. Bu nedenle mümkün olduğu kadar kendimle ilgili az bilgi giriyorum." (K6, ekşi)

"Bu durum sosyal medyanın ve hatta yeni medyanın genel bir problemi ve tabi ki bundan rahatsızlı duyuyorum ancak bu konuda mahremiyet peșine düştüğümüzde bir defter ve bir kalem kullanmaktan başka çaremiz yok." (K5, ekşi)

"Ben kendi imajımı satıyorum zaten trend bu, buna ayarlandım. Mail adresimin başka kuruma verilmesi çok da büyük skandal değil.” (K11 ekşi)

“Çok önemsemiyorum. Çünkü en basit bir platformda hesap açarken paylaşmamakta prensip edindiğim şeyler var. İlla bana o bilgiyi vereceksin diyorsa ben de vermeyeceğim diyorum. Ve başlamadan bitmiş oluyor." (K12 ekşi)

\section{Sonuç}

Klasikanlamdaki maddi meta'nın, maddi olmayan meta'ya dönüşmesi “yeni medyanın ekonomi politiği" meselesindeki en önemli sacayağı olarak görünmektedir. Buna göre, her ne kadar üretilen (maddi olmayan) meta "yer kaplayan" maddi bir ürün olmasa bile, yine de üretim aracının sahibine kâr üretmesi anlamında değerinden bir şey kaybetmez. Ancak maddi/klasik meta'nın aksine, dijital platformda üretilen maddi olmayan meta, bizim örneğimizde kullanıcılar tarafından üretilen içerik ve kullanıcı verileri, üreticisine, bizim örneğimizde "kullanıcı", hiçbir ücret kazandırmamaktadır. Fuchs'un da belirttiği gibi "Metaları üreten üreticiler vardır, aksi halde var olamazlardı." Bu anlamıla üretilen kâr, tümüyle üretim aracının sahibinde birikmektedir. Yapılan görüşmelerde kullanıcıların bir kısmı bu türden bir ücretsiz çalışma durumundan rahatsız olduklarını belirtmişler öte yandan diğer bir kısmı rahatsız olmadıklarını belirtmiş̧lerdir. Dallas Smythe'ın kavramsallaştırdığı "izleyici metası" nosyonuyla paralel olarak burada da kullanıcılar içerik üretimi ve bu üretim için harcadıkları "zaman" vasıtasıyla somut bir "değer" yaratmaktadırlar. Bir başka ifade ile, üretim aracının mülkiyetine sahip olanlar için, soyut/maddi olmayan bir meta yolu ile "somut" bir kazanç üretirler. Nasıl ki sermaye sınırlılıklarından kurtulup küresellești ise, benzer şekilde artık emek ve meta üretimi de mevcut sinırlılıklarından kurtulmuş, fabrika gibi mekan-bağımlı olma durumundan kurtulmuş, bütün yeryüzü -internetin olduğu bütün yeryüzü- bir meta üretim fabrikasına dönüşmüştür. Jhally'in isabetli vurgusu ile "bütün gezegen kapitalist bir fabrika haline gelmiştir."

Kullanıcı tarafından üretilen içerikle çalışan sosyal medya siteleri kullanıcıların internet ağları üzerinde bilgi ve fikir üretmeleri ve paylaşmaları için kullandıkları araçlardır. Dijital emek sosyal medya ağlarına artan katılımın ardından tipik olarak iş olarak görülmeyen kapitalist üretim biçimleri içinde bir dizi duygusal ve sosyal aktiviteyi tanımlamak için kullanılmaya başlanmıştır. Kısaca dijital emek konusu, sosyal medya için içerik oluşturulmasındaki ödenmemiş emeğin sömürülmesini içermektedir. Çalışmamızda görüștüğümüz yazarlara göre sözlükler gündemi takip etmek, fikirlerini özgürce paylaşmak, sosyalleşmek, zaman geçirmek ve yazar olma hissini yaşamak için önemli bir alandır. Çalışmada ikinci varsayımımız katılımcı sözlük yazarlarının içerik üretirken temel motivasyonları "ücret” değil kimlik ve aidiyet olduğudur. Bu varsayım ile ilgili hazırladığımız soruya yazarlar otomatik dinleyiciye sahip oldukları, anonimlik ortak entellektüel çalışma mekânı olduğu ve İçeriğe katkıda bulundukları için sözlükte yazdıklarını belirtmişlerdir. Katılımcı 
sözlük yazarları içerik üretirken bunu bir iş olarak görmemektedir biçimindeki varsayım ile ilgili yazarların üçte ikisi çalışma olarak görmediklerini üçte biri ise çalışma olarak değil emek olarak değerlendirileceğini vurguladılar.

Katılımcı sözlüklerde kimlik ve aidiyet oluşturmak için yazan yazarlar aynı zamanda şirketler için artı değer üreten meta üreticilerine dönüşmektedir. Katılımcı sözlük kullanıcıları meta üretiminin bir parçasıdır. Yazarların çoğunluğu bu konu ile ilgili gönüllük kavramının altını çizmişlerdir. Katılımcı sözlük yazarlarının ürettikleri içerikler ve kullanıcı verileri metaya dönüşmektedir. Yazarların yazdıkları maddeler ve yazarların bilgileri şirketlerin mülkiyetine geçmektedir. Kullanıcı bilgilerinin reklam verenlere ya da ikincil kurumlara verilmesi konusunda görüşme yapılanların üçte biri endişe taşımaktadır. Diğer görüşmecilerin büyük bir bölümü ise sözlüklerin anonim yapısı nedeniyle bu durumdan endişe duymadıklarını söylemişlerdir. 0 halde sorulması gereken soru şudur: Neden kullanıcılar hiçbir ücret almadan içerik üretmekte, yani meta üretmektedirler? Bu motivasyonun cevabı yapılan görüşmeler ışığında şu şekilde verilebilir: Kullanıcılar bu çalışma süresini bir "mesai" olarak tanımlamamakta, bunu daha çok "eğlence" olarak görmektedirler. Burada dikkat edilmesi gereken temel husus kullanıcıların geliştirdikleri "aidiyet" duygusu ve "kimlik"lerdir. Özetle, sosyal ağlar üretim aracı olmalarına rağmen hayatta kalma araçları değildir. Üretici bu araçları kullanırken keyif alması nedeniyle bu araçları kullanmayı arzular, burada üreticinin hiçbir ücret almamasına rağmen üretim yapmasının sebebi bu türden bir arzu'dur. Öte yandan fabrikada üretim yapan bir işçi hayatta kalmak için orada bulunmak zorundadır, bunu arzulamaz. Katılımcı sözlükler de yazar olarak yer alan sözlükleri iletişim ve üretim aracı olarak kullanmaktadırlar.

\section{Kaynakça}

Binark, M. Kılıçbay, B. (2005). İnternet, Toplum, Kültür, Ankara: Epos Yayınları.

Bottomore, T. (2005) Marksist Düşünce Sözlüğü, (M. Tunçay, Çev.). İstanbul: İletişim Yayınları. (1983)

Castells. M. (2008). Enformasyon Çağı: Ekonomi, Toplum Ve Kültür A $\breve{g}$ Toplumun Yükselişi, (E. Kılıç, Çev.). İstanbul: İstanbul Bilgi Üniversitesi Yayınları.

Castells. M. (2016). İletişim Gücü. (E. Kılıç, Çev.). İstanbul: İstanbul Bilgi Üniversitesi Yayınlarl.

Demir, O. Ö., (2011) Nitel Araştırma Yöntemleri, K. Böke, (Der). Sosyal Bilimlerde Araştırma Yöntemleri, 3. Baskı, İstanbul, Alfa Yayınları.

Dijk, J. V. (2016), Ağ Toplumu, (Ö. Sakin, Çev.), İstanbul: Epsilon Yayıncılık. (2006).

Fuchs, C. (2014). Bilişsel Kapitalizm ya da Enformasyonel Kapitalizm? Enformasyonel Ekonomide Sınıfın Rolü. M. A. Peters ve E. Bulut (Ed.), Bilişsel Kapitalizm: Eğitim ve Dijital Emek (s. 137-189). İstanbul: Notabene Yayınları.

Fuchs, C. (2016). Sosyal Medya Eleştirel Bir Giriş, (D. Saraçoğlu, İ. Kalaycı, Çev.). İstanbul, Nota Bene Yayınları. (2013)

Fuchs, C. Mosco, V. (2015), Marx Geri Döndü Medya, Meta ve Sermaye Birikimi, İstanbul: Nota Bene Yayınları.

Fuchs, C. (2016). Dijital Emek ve Karl Marx, (T. E. Kalaycı, S. Oğuz, Çev.). İstanbul, Nota Bene Yayınları. 
Fuchs, C. and Sevignani, S (2013) What is digital labour? What is digital work? What's their difference? And why do these questions matter for understanding social media? tripleC: Communication, Capitalism and Critique. Open Access Journal for a Global Sustainable Information Society, 11 (2). pp. 237-293.

Fuchs, C. (2010). Labour in Informational Capitalism. The Information Society 26 (3): 176-196.

Gürel, E ve Yakın, M. (2007). Ekşi Sözlük: Postmodern Elektronik Kültür. Selçuk Üniversitesi İletişim Fakültesi Akademik Dergisi, 4 (4), 203-219.

Hardt M.ve Negri A, (2005). Imparatorluk, (A. Yılmaz, Çev) İstanbul: Ayrıntı Yayınları.

IAB Türkiye, (Nisan, 2018). İnternet Ölçümleme Araştırması Nisan Overnight Raporu, Erişim: 10 Mayıs 2018, http://www.iabturkiye.org/UploadFiles/ TopTwentyFiles/Internet_audience_toplist_04_2018_Overnight.pdf

Jenkins H. (2016). Cesur Yeni Medya, (N. Yeğengil, Çev.). İstanbul: İletişim Yayınları. (2006)

Jenkins, H. Ford, S ve Green J.(2013). Spreadable Media: Creating Value and Meaning in a Networked Culture, New York: New York University Press.

Jhally (1987). The Codes of Advertising: Fetishism and the Political Economy of Meaning in the Consumer Society, New York: St. Martin's Press and Frances Pinter.

Laughey, D. (2010) Medya Çalışmaları: Teoriler ve Yaklaşımlar, (A.Toprak, Çev) İstanbul: Kalkedon Yayınları. (2009)

Lazzarato, M. (1996) "Immaterial Labor." Paolo Virno ve Michael Hardt (Der), In Radical Thought in Italy: A Potential Politics, 133-50. Minneapolis: University of Minnesota Press.

Maigret, E. (2012). Medya ve İletişim Sosyolojisi, (H.Yücel Çev) İstanbul: İletişim Yayınları.

Marx, K. (2008) Grundrisse, İstanbul: Birikim Yayınları.

Netchitailova, E. (2012). The Flâneur, the Badaud and Empathetic worker, Erişim: 10 Nisan 2018, https://www.triple-c.at/index.php/tripleC/article/ view/500/639

Peters M A, Bulut E. (2014). Bilişsel Kapitalizm, Eğitim Ve Dijital Emek, İstanbul: Notabene Yayınları.

O’Reilly T. ve Battele, (2009). Web Squared: Web 2.0 Five Years On, Erişim: 10 Nisan 2018, https://conferences.oreilly.com/web2summit/web2009/public/ schedule/detail/10194,

Poe, M. T. (2015), İletişim Tarihi, (U. Y. Kaya Çev) İstanbul: Islık Yayınları.(2010)

Ritzer, G. Jurgenson N, (2010) Production, Consumption, Prosumption: The nature of capitalism in the age of the digital 'prosumer', Journal of Consumer Culture.s V.10.1.13-36.

Salecl, (2008). Kaygı Üzerine, (B.E. Aksoy, Çev), İstanbul: Metis Kitap.(2004)

Terranova T, (2000) Free Labor: Producing Culture for the Digital Economy. Social Text 18(2 63) 
Timisi. N. (2003). Yeni İletişim Teknolojileri ve Demokrasi, Ankara: Dost Kitapevi.

Toffler A. (1980). Üçüncü Dalga, (S. Yeniçeri, Çev) İstanbul, Koridor Yayıncılık.

Turkle S. (2015) Reclaiming Conversation: The Power of Talk in a Digital Age, Penguin Publishing.

Uçkan, Ö. (2012). Sözlükler: Türkiye İnternet Kültürünün Vazgeçilmezi. Bilişim Dergisi, 140, 22-27

Yazıcıoğlu, Y. ve Erdoğan, S. (2004). SPSS Uygulamalı Bilimsel Araştırma Yöntemleri, Ankara: Detay Yayınları. 
